\title{
Tweet carefully, Museums: A Case Study of the \#decolonizeourmuseums Protest
}

By Natalie Ume Liverant

A dissertation submitted to Victoria University of Wellington

In partial fulfilment of the requirements for the degree of Master of Museum and Heritage Studies

Victoria University of Wellington

2017 


\section{Table of Contents}

Acknowledgements......................................................... 3

Abstract....................................................................... 5

Introduction, Literature Review and Research.................................... 6

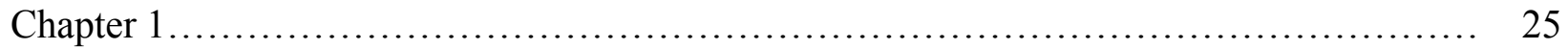

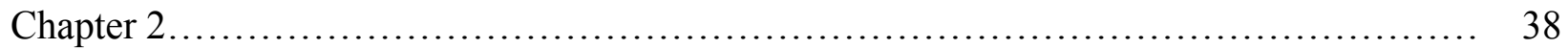

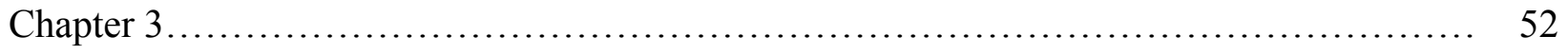

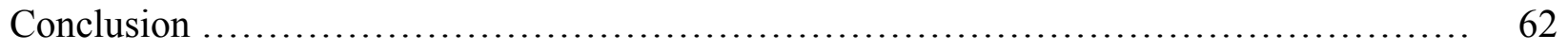

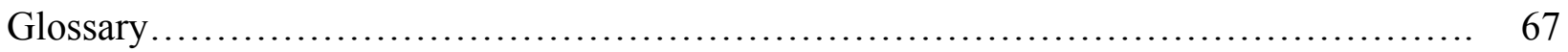

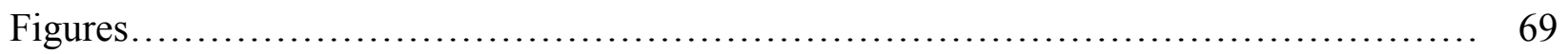

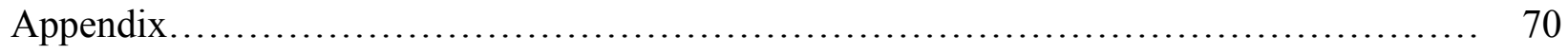

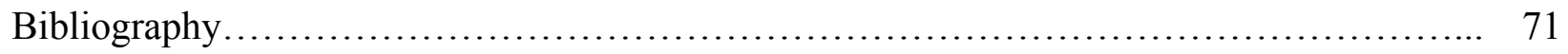

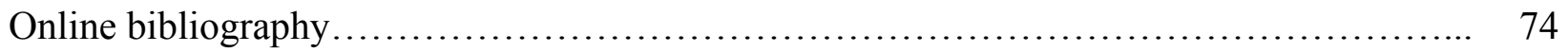




\section{Acknowledgements}

The finality of this dissertation would not have happened without the support and encouragement of a community of people who surround me. I would like to acknowledge a handful of them here. Lee Davidson, my supervisor, despite the larger than normal number of masters students this year needing your help and advice, several classes, and a project of your own, you took the time when I needed it, to arrange meetings and talk me through the challenges encircling this project and my life, as an international student, in New Zealand. Thank you for your time, encouragement, and honest words. I am extremely grateful for your support.

To my Mom, Darlene, and my sister, Stephanie, for all their love, support, care packages, and hours set aside for planned or spontaneous Skype and FaceTime calls.

I owe a great deal to my friend, Josie Hana Henning, who, without a doubt, was a large contributor in my decision to pursue another expat experience in Aotearoa, New Zealand, and a source of endless advice, chocolate, comfort and encouragement. 池野博司手伝ってくれてあ りがとう。 My friends and ex-flatmates, Melissa Wells and Sophie King, thank you for the laughs, Harry Potter themed study 'breaks' and all-around girlie support and encouragement. And lastly, to numerous teammates at Narukami Taiko, a great source of decompression, musical exercise, laughs, food, and support. Learning to drum with you all has filled my heart and steps with san doko. Don kara ka.

Thank you. 非常に感謝してます。 


\begin{abstract}
Tweet Carefully, Museums presents an in-depth case study of audiences and a museum using social media in the current Web 2.0 age. It explores online protest and controversy over an event held at the Museum of Fine Arts, Boston (MFA) in 2015. This dissertation addresses a current gap in the literature centred on public use of social media as a platform to engage in museumcentred debate and discussion. At the moment, literature discussing new technologies in museums focuses heavily on an institution-to-audiences model. While this is indeed useful information, there is another aspect of digital media that has been largely neglected. In their case study, Gronemann et al. observed that overall, museums distanced themselves from discursive co-construction in their Facebook posts. The lack of engagement with audience can have adverse effects as social media grows in its popularity to mobilise the public in the name of social justice. "Western" museums, many of which have a history of fostering colonial narratives, can also be perceived as authoritative institutions. Museums need to engage more conscientiously with their online audiences. Unconsidered or insensitive engagement over social media may have adverse effects on institutions.
\end{abstract}

Kimono Wednesdays was an event where the public was invited to try on kimono in Gallery 255 at the MFA. The MFA advertised the event on a few social media platforms. On Facebook, the advertisement drew the harshest criticisms from a section of the Asian-American community. The sensational attention on Facebook grew quickly into physical protest inside Gallery 255. This case study analyses a sample of the dialogic posts, comments, and replies left on Facebook during the protests. It also analyses a symposium organised by the MFA, Kimono Wednesdays: A Conversation, where a panel made up of academics, museum staff, and a protester discussed the various concepts and perceptions of the museum's controversial advertising and event.

This case study demonstrates that social media is a double-edged sword for museums, as it is a useful tool, but presents uncomfortable challenges. The key findings from this study show how content on the internet can be misinterpreted and how implicit bias can occur from any institution. As museums embrace Web 2.0 applications, they too must become more aware of their online presence and set in place methods of dialogic co-construction so as to better understand and communicate with the diversifying cultures that surround them. 


\section{Introduction, Literature Review and Research \\ Museums on Social Media}

\section{Introduction}

On a Wednesday evening in June of 2015, a small group of Asian-Americans attended an event at the Museum of Fine Arts, Boston (MFA). Inside Gallery 255, the public eagerly waited to try on a finely embroidered uchikake (打掛) with the depiction of Taira no Koremochi (平維茂), a character from a traditional noh and kabuki play, Momijigari (紅葉狩, translated as Maple Viewing). Alongside the excited participants, the Asian-Americans in attendance held up posters in protest: 'Try on the kimono, learn what it is like to be a racist imperialist!!! Today!!! ${ }^{1}$ Despite the disruption, the event went on as planned.

Protesters attended the event in Gallery 255 every Wednesday evening until the event's scheduled completion. Publicity of the protests had spread like wildfire. Within the first week, the protesters had organised themselves and created a Facebook group called "Rage Against Yellow Face". As the attention around the protests grew, counter-protesters also organised themselves online and in the museum. Eventually the Facebook group found it necessary to rebrand, organising themselves on a Tumblr page called "Decolonize Our Museums", and on Twitter via the handle "@decolonizeOM” using the hashtag: \#decolonizeourmuseums. ${ }^{2}$ Both the protester and counter-protester groups grew to sizeable numbers. The MFA, compelled to

\footnotetext{
${ }^{1}$ See Japanese-American in Boston, "Part 1: Kimono Wednesdays Protest Postmortem: Media, Public, Critics," blog post, July 10, 2015 (22:03PM), accessed January 27, 2017, http://japaneseamericaninboston.blogspot.co.nz/2015/08/part-1-kimono-wednesdays-protest.html; Stephanie McFeeters, "Counter-Protesters Join Kimono Fray at MFA," Boston Globe, July 19, 2015, accessed January 27, 2017, https://www.bostonglobe.com/arts/2015/07/18/counter-protesters-join-kimono-fraymfa/ZgVWiT3yIZS1QgxCghAOFM/story.html; Seph Rodney, "The Confused Thinking Behind the Kimono Protests at the Boston Museum of Fine Arts," Hyperallergic, July 17, 2015, accessed July 7, 2016, https://hyperallergic.com/223047/the-confused-thinking-behind-the-kimono-protests-at-the-boston-museum-offine-arts/

${ }^{2}$ Tumblr is a type of microblogging akin to Facebook. Users can post, repost, and share with their networks. Twitter is another form of microblogging that limits the user to 140 characters, rather than a post. This is referred to as a tweet. A tweet can also include images and links to other sites on the Internet. Profiles on Twitter are called handles and utilise the @ symbol in the name. This allows people to connect to other profiles, mention other accounts in a tweet or send messages. The hashtag, or \#, is a linking mechanism that allows users to click on it and see other tweets that utilise the same keyword or topic.
} 
appease both sides and minimise any possible violence or further controversy, chose to alter the event and issue a public apology. ${ }^{3}$

While museum criticism and controversy has occasionally arisen in traditional print media, we are now in what the New York Times columnist Thomas Friedman calls: "The Age of Protest" 4 His January 2016 interview with Dov Seidman explored the current climate of moral outrage and response. Seidman's perspective was that moral outrage is a good thing, with the caveat that it can only be useful and effective when there is moral conversation and a deeper level of engagement and reflection to resolve deeply emotional disputes. Elsewhere, he stated, "we're living in a never-ending storm". This storm is the cyclical environment where a protest inspires change, yet there is a group, or groups, who protest and resist the new change, oftentimes halting progress, resulting in a resolution that is unclear and short-lived. The protests and counterprotests that were a part of the Kimono Wednesdays event at the MFA illustrate this.

Under the current temperament of audiences on social media, are museums, as institutions that handle social and cultural information and have a history of imposing a dominant perspective, prepared to be a part of an evolving social landscape? ${ }^{5}$ Museum literature on new technologies and digital media is dense, particularly in the embrace of growth and development alongside a prosumer generation. ${ }^{6}$ However, there appears to be a gap in discussions of public audiences' use of social media to engage with, and about, museums and their content. Given that social media can be used as a powerful tool for public shaming, it seems necessary that there be more research. This came to my attention when an article about the \#decolonizeourmuseums protests surrounding the MFA, described above, appeared in my Facebook newsfeed.

\footnotetext{
3 “Press: July 2015," Museum of Fine Arts, Boston, accessed July 2, 2016, http://www.mfa.org/news/2015/july

${ }^{4}$ Thomas L. Friedman, "The Age of Protest," The New York Times, January 13, 2016, accessed February 2, 2017, https://www.nytimes.com/2016/01/13/opinion/the-age-of-protest.html

${ }^{5}$ Amy Lonetree, Decolonizing Museums: Representing Native America in National and Tribal Museums (Chapel Hill, NC: University of North Carolina Press, 2012).

${ }^{6}$ Prosumer is a reference to a consumer who takes part in designing or customising a product for their own needs. See Valentina Fois, "The Prosumer: The Key Player of the Museum of the Future," Proceedings of the Conference on Electronic Visualisation and the Arts (EVA '15): 291-297, accessed January 28, 2017, https://doi.org/10.14236/ewic/eva2015.32.
} 
To explain the genesis of the protest: the MFA held an exhibition on the topic of Japonisme in Europe. ${ }^{7}$ This exhibition included the painting, La Japonaise, by Claude Monet. The painting was among many collected works of European impressionist $\operatorname{art}^{8}$ and objects created under the influence of Japanese aesthetics from the late 1850s. La Japonaise, having recently undergone an extensive year-long conservation, was the main attraction for the Japan leg of an international tour. NHK, the Japanese national broadcasting company and partial sponsor of the exhibition, had researched the images depicted on the uchikake garment, once worn by Camille Monet, as seen in the painting. Grasping an opportunity to create a tactile and engaging educational program, NHK had two replicas of Camille's uchikake created for a special 'La Japonaise workshop' (ラ・ジャポネースワークショップ) in Japan. These limited-access workshops permitted some members of the public to become a "la japonaise" or Japanese woman, themselves, posing in the uchikake and having their photo taken.

The mind-bending setup of having a predominantly Japanese audience dress up as a French woman impersonating a Japanese woman, who was then immortalised by a French impressionist, was an uncontroversial and popular event. The contradiction of an audience, predominantly Japanese, wanting to dress up in an object of their own heritage as it was depicted by a French impressionist, appears to have been well received in Japan. Enthusiastic to provide audiences in Boston with a similar unique experience, the MFA requested the two replica uchikake from Japan, for which NHK obliged. Unfortunately, the opening of the special event and the discussions following, Claude Monet: Flirting with the Exotic and Kimono Wednesdays, held in Gallery 255, were met with mixed feelings. ${ }^{9}$ Initially, many of the MFA's Facebook and Instagram audience members wrote comments that they were excited to have the opportunity to try on the kimono, as it was referred to by the MFA. However, as publicity grew, posts expressing disgust and disappointment manifested around the semantics of the advertising and the perceived "minstrelsy" of the event. ${ }^{10}$ The protest in the gallery awakened controversy

\footnotetext{
${ }^{7}$ Japonisme is a French term, coined in the 1870 s, for the style of European artists incorporating Japanese aesthetics into their artwork. This began sometime in the $1850 \mathrm{~s}$ and continued into the $1870 \mathrm{~s}$.

${ }^{8}$ Impressionism refers to a style of artwork where the images are not painted in great detail, but instead use vibrant and bold strokes of colour to elicit the impact of light and movement to the viewer.

9 “'Special Event: Cheers to Malcolm!” Museum of Fine Arts, Boston, accessed January 28, 2017 , http://www.mfa.org/programs/special-event/cheers-to-malcolm

${ }^{10}$ This will be discussed further in chapter 3.
} 
online. The Facebook group, Rage Against Yellowface, became the platform from which both supporters and protesters of the event declared their opinions and feelings. All the while, the MFA remained noticeably silent about the situation rising around them.

Protests around museum exhibitions are not new. In 1998, New Zealand's national museum, Te Papa Tongarewa, received national attention when an object in a touring exhibition, Pictura Britannica, offended some of the museum's Christian visitors. ${ }^{11}$ The object at the heart of the controversy was a 75-millimeter-tall statue of the Virgin Mary encased in a latex condom, created by British artist, Tania Kovats. ${ }^{12}$ Over the course of six weeks, protesting and counterprotesting ensued. Each side had personally invested viewpoints on religion and art that raised the question of how art should and should not be censored for the museum's diverse demographics. $^{13}$

There are undeniable parallels between the "Virgin in a Condom" protests and Kimono Wednesdays. Both protests were organised by people who felt the museums were disrespecting cultural or religious perspectives. There were also feelings held by many that the institutions had ignored their complaints, consequently spurring them to protest, escalating the public attention through various media. However, one particular element differentiates the two case studies. "Virgin in a Condom" occurred 17 years before Kimono Wednesdays. In the time between these two events, the Internet had transitioned from a flat platform that imitated traditional media interactions (e.g. conversation and communication mostly initiated and dominated by institutions), into social media hubs, where people, regardless of background, could interact and engage with diverse topics. While the arguments made by the protesters of "Virgin in a Condom" made headlines in New Zealand, there was not insomuch as a ripple that can be found of the incident being reported outside the country. Whereas, Kimono Wednesdays garnered international attention through the now defunct "Rage Against Yellow Face" Facebook page;

\footnotetext{
${ }^{11}$ Ryan Brown-Haysom, "Religious Objects in Museums: Private Lives and Public Duties. (Book review)," review of book by Crispin Paine, Museum Worlds 2 (2014): 235-240.

${ }^{12}$ Andrea O’Neil. “'Virgin in a Condom' artwork provoked violence month after Te Papa Opening," The Dominion Post, March 21, 2015, accessed May 30, 2016, http://www.stuff.co.nz/dominion-post/capitallife/67466278/virgin-in-a-condom-artwork-provoked-violence-month-after-te-papa-opening

${ }^{13}$ Vic Francis. "Virgin in a Condom Provokes Outcry," Christianity Today, June 15, 1998, accessed February 20, 2017, http://www.christianitytoday.com/ct/1998/june15/8t719b.html
} 
hashtags on Twitter: \#decolonizeourmuseums, \#kimonowednesdays; and various other Facebook groups, such as "Support For Kimono Wednesdays at BMFA"; as well as a sea of blogs, vlogs, and online editorials from people in the U.S., Japan, and elsewhere. ${ }^{14}$

This case study of the Kimono Wednesday protests examines how audiences are using the social media application Facebook as a platform for discussion and critique of a museum. In this dissertation, I have excavated timelines of conversations on Facebook posts that discuss the MFA's event: Kimono Wednesdays. I specifically targeted online posts and comments that mention Kimono Wednesdays, Boston MFA, or Decolonize Our Museums (DOM). The objective of this research is to draw attention to the validity of future discussions regarding museums' and audiences' use of social media as a tool for dialogic co-construction. From a review of the current museum literature and an analysis of the arguments and comments around the MFA's event, I present my findings.

This dissertation is divided into three chapters, an introduction and a conclusion. The Introduction includes an outline of the aims and objectives of this research. Following this is a discussion of the existing literature and research methodology. Chapter 1 describes the story of Claude Monet's La Japonaise, the painting at the centre of the protest mentioned above; the acquisition of the painting by the MFA; the successful run of La Japonaise as the star attraction in the travelling exhibition: Looking East: Western Artists and the Allure of Japan; and the marketing that sparked outrage when the MFA created their own event. Chapter 2 analyses the comments and discussions around Kimono Wednesdays from Facebook. Chapter 3 reviews the various arguments raised and addressed during a symposium uploaded to YouTube that was orchestrated by the MFA in February of 2016. The Conclusion reviews the findings of the case study and a proposal for further research and discussion regarding development of new coconstructive strategies that centre on social media applications within museums. A final note about the content of this dissertation: much of the language used is a mix of American English,

\footnotetext{
14 "Support for Kimono Wednesday's [sic] at BMFA,” Facebook group, accessed October 22, 2016, https://www.facebook.com/groups/1141781712515378; Shaun O’Dwyer. "Of Kimono and Cultural Appropriation," The Japan Times, August 4, 2015, accessed October 22, 2016, http://www.japantimes.co.jp /opinion/2015/08/04/commentary/japan-commentary/kimono-cultural-appropriation/; Decolonize Our Museums, Twitter Page, accessed October 20, 2016: https://twitter.com/decolonizeom
} 
New Zealand English, Japanese, and (sparingly) a bit of French, in order to stay honest to content and context as much as possible. I felt it particularly important to use native words as much as possible, including the use of non-Romanised characters when describing Japanese objects. Other subtle spelling differences, such as American words that often drop the letter $-\mathrm{u}$, as in color, have also been used when taken in the form of quotes.

\section{Literature review}

This next section discusses the existing literature on museums' cultural narrative and the use of social media. The traditional messages of cultural narration are being challenged, particularly as the population of Western audiences becomes increasingly more diverse. ${ }^{15}$ Henning describes museums as "memory machines" that are the "technical means by which societies remember [and] devices for organizing the past for purposes of the present". ${ }^{16}$ As the cultural demographic shifts, so do the interests of audiences change, and technology is adopted to cater for the audiences' perceived needs. ${ }^{17}$ According to Black, in order for museums to stay relevant to future audiences, there needs to be in place "long-term strategies in response to a perfect storm of three crucial elements: demographic change, generational shift and the rise of new media". ${ }^{18}$ Within the last decade, there has been an increasing amount of literature on the topic of partnership, inclusion, and engagement with culture and communities; less literature exists on the application of social media as part of this process. ${ }^{19}$

${ }^{15}$ Graham Black, "Developing Audiences for the Twenty-First Century Museum," in The International Handbooks of Museum Studies: Museum Practice, 1st edition, ed. Conal McCarthy (Chichester, West Sussex: John Wiley \& Sons, Ltd., 2015), 125.

${ }^{16}$ Michelle Henning, Museums, Media, and Cultural Theory: Issues in Cultural and Media Studies (London: McGraw-Hill Education and Open University Press, 2006), 129.

${ }^{17}$ Black, "Developing Audiences," 125; Nina Simon, The Participatory Museum (Santa Cruz, CA: Museum 2.0, 2010); Bernadette Lynch, Whose Cake is it Anyway?: A Collaborative Investigation into Engagement and Participation in 12 Museums and Galleries in the UK (Summary Report) (London: Paul Hamlin Foundation, 2011).

${ }^{18}$ Black, "Developing Audiences," 125.

${ }^{19}$ Bernadette Lynch. Our Museum: A Five-Year Perspective from a Critical Friend (London: Paul Hamlyn Foundation, 2016); Simon, Participatory Museum; Sigurd Trolle Gronemann, Erik Kristiansen and Kirsten Drotner, "Mediated Co-construction of Museums and Audiences on Facebook," Museum Management and Curatorship 30 (2015): 174-190. accessed September 7, 2015, doi: 10.1080/09647775.2015.1042510. 
Social media is changing rapidly and not staying up to date with the way people are using it can have overwhelming effects. In an exit interview discussing his last days as President of the United States and the outcome of the 2016 election, Obama stated:

One of the challenges that we've been talking about now is the way that social media and the Internet have changed what people perceive as news. ... people are getting a hundred different visions of the world from a hundred different outlets or a thousand different outlets, and that is ramping up divisions. ... if we are gonna [sic] solve that, it's not going to be simply an issue of subsidizing or propping up traditional media; it's going to be figuring out how do we organize in a virtual world the same way we organize in the physical world. We have to come up with new models. ${ }^{20}$

The same argument that Obama is making about the current state of news media can be made for museums. Museums need to develop new strategies for engaging and developing narratives that differ from the traditional non-Internet-based approaches they previously employed. Just as for the White House, social media provides museum audiences with the chance to share and create content that can be at odds with the message or perspective the institution shares. In many ways, this challenges the traditional notion of museums as a powerhouse of knowledge and history:

... new media that has appeared (inviting addition and amendment)... [is] at odds with notions of fixity or closed authorship in the museum.... Rather than being inviolate, authorship in the digital world [is] a continuing process... on the digital network all users could suddenly become authors. The instantaneous, usergenerated content of the Web, the new social software suddenly [gives] all visitors a microphone, the opportunity to rewrite the script to reposition the camera, and to rearrange the props. ${ }^{21}$

Despite the challenges of authorship, many institutions promote themselves online over social media platforms such as Facebook and Twitter. In 2012, Fell observed how Te Papa Tongarewa, the National Museum of Aotearoa New Zealand, used social media within several of its departments. Through interviews with staff, she discovered that the aims and objectives for the

\footnotetext{
${ }^{20}$ Jan S Wenner, “The Day After: Obama on His Legacy, Trump's Win and the Path Forward," Rolling Stone, November 29, 2016, accessed December 15, 2016, http:/www.rollingstone.com/politics/features/obama-on-hislegacy-trumps-win-and-the-path-forward-w452527

${ }^{21}$ Ross Parry, Recoding the Museum: Digital Heritage and the Technologies of Change (London and New York: Routledge, 2007), 107-108.
} 
use of social media were different in each department. ${ }^{22}$ Some of the uses highlighted in Fell's work include: the promotion or marketing of events; providing information pertaining to collections and historical information, and as a method to engage with other cultural institutions, particularly in discourse related to the management and curation of online content. Fell's work highlights how museums can work to engage online audiences. However, her observations only discuss online discourse between museum and audience in the form of negative feedback. In other words, a customer having a poor experience and making a complaint over one of the Museum's social media platforms. ${ }^{23}$ Though it is certainly important to engage in customer service online, there are broader aspects for which social media can be used to connect with, instead of to, audiences.

The following section of the literature review offers several topics to consider in the social evolution of the Internet. This includes shifts in user demographics and the applications for which it is used. In looking towards the future, museums will need to consider stronger coconstructive discourse with audiences online. The challenge at this time is the lack of existing theory or method on the best ways to do this. Instead, I will discuss literature with a focus on social challenges such as decolonising museums and common trends of social applications online.

\section{Museum perceptions, identity and new media}

In her nine-minute TEDxDirigo Talk, Cinnamon Catlin-Legutko explains how museum practices are based on traditional methods of the colonial perspective. A predominantly Western concept, museums in the U.S. portray a perspective where Europe remains "the ideal image". This is as problematic because most modern societies are growing in diversity, and this European narrative does not reflect the perspectives of the entire audience. ${ }^{24}$ She emphasises how displays in North America of non-Western cultures are portrayed in halls that revolve around an evolution story

${ }^{22}$ Georgina Fell, "Going Social: A Case Study of the Use of Social Media Technologies by the Museum of New Zealand Te Papa Tongarewa," reCollections, Volume 9, Issue 1 (April 2014), ISSN 1833-4946, accessed May 6, 2016, http://recollections.nma.gov.au/issues/volume_9_number_1/papers/going_social

${ }^{23}$ Fell, "Going Social," 28.

${ }^{24}$ Cinnamon Catlin-Legutko, We Must Decolonize Our Museums |Cinnamon Catlin-Legutko | TEDxDirigo. YouTube video, 9:23, posted by “Tedx Talks," December 6, 2016, https://www.youtube.com/watch?v=jyZAgG8$-\mathrm{Xg} \& \mathrm{t}=316 \mathrm{~s}$ 
(e.g. biological cells, Africa, Neanderthals and early Europeans, Native Americans). Her brief but insightful talk sheds light on issues of historical perspective as well as raising questions about representation and authority.

A pre-cursor to Catlin-Legutko, Lonetree has worked and learned to preserve and share indigenous perspectives in a museum. She describes the current situation of handling indigeneity in museums:

Privileging Indigenous voices and perspectives, challenging stereotypes that have dominated museums' representations of the past, and serving as sites of "knowledge making and remembering" for our own communities and the general public are only the beginning of decolonizing museum practice. ${ }^{25}$

In addition to having some measure of oversight or creative control, museums must assure their minority communities that the narratives presented within their halls will emphasise and respect the uniqueness of individual peoples rather than relegating them to generalities in halls titled "Native Americans" or "Africa". The process to decolonise a museum is arduous, as it requires a change of mind in the both the staff and the greater museum community. Extensive, ongoing, collaborative projects and discussions will assure that the narratives depicted by these institutions represent the voices of the people. ${ }^{26}$

One powerful reason to decolonise museums is the increasing rate of diversity within traditionally "white" populations. ${ }^{27}$ An ongoing report by Statistics New Zealand has observed the evolution of diversification within the country. There has been, the study noted, a centurylong challenge to accurately collect the numerical data of cultural diversity in New Zealand. ${ }^{28}$ This is largely due to a growth in migration. The study noted that an increase of migrant communities in urban areas has led to higher rates of mixed ethnic unions and offspring. In turn, this has effected how people choose to self-identify, making definitions of identity more

\footnotetext{
${ }^{25}$ Lonetree, Decolonizing Museums, 171.

${ }^{26}$ Lonetree, Decolonizing Museums, 172-173.

${ }^{27}$ For this dissertation, a "Western museum" refers to an institution in a country that has a history of European colonisation. This includes invasion, occupation, and/or ownership by a European country or nation.

${ }^{28}$ Mansoor Khawaja, Bill Boddington, and Robert Didham. Growing Ethnic Diversity in New Zealand and its Implications for Measuring Differentials in Fertility and Mortality (Wellington: Statistics New Zealand, 2007), accessed February 17, 2017, http:/www.stats.govt.nz/ /media/Statistics/browse-categories/population/censuscounts/review-measurement-ethnicity/growing-ethnic-diversity.pdf, 4-16.
} 
complex. ${ }^{29}$ Population change hasn't gone unnoticed in the museum sector, either. Studies on visitors help to clarify to researchers and the institution just who is coming to a museum and who isn't. But, just as in the report by Statistics New Zealand, relying on demographic markers is proving to be inefficient. ${ }^{30}$ Greater emphasis is now being directed toward observing changes in social behaviours by younger populations, as it is knowing and understanding the impact of these changes that is crucial to reaching out and appealing to new audiences. ${ }^{31}$

The generational shift cannot be discussed separately from the rise in new media. In the mid1990s, Fahy described the "INTERNET" [sic] as a tool that provides an "opportunity to completely change the ways in which museums communicate internally and with external bodies". ${ }^{32}$ Her understanding of the Internet was as an academic meeting space where the profession could unify and find common ground in a time and place that was "much faster than had hitherto been possible". ${ }^{33}$ As she looked toward the future of museums, Fahy believed that technology could harness scholarly exchange, benefiting the operations of the institution, the relationships between museums on a national and global scale, and the museum audience. ${ }^{34}$ Fahy's vision of internet usage has become common practice for museums. Today, institutions provide access to information about objects, events, exhibitions, conferences, and partnerships, and even show off key selections from the museum store, through websites and social media platforms. ${ }^{35}$ However, there is an aspect of the "INTERNET" that Fahy did not foresee: this is what is currently referred to as Web 2.0.

\section{Web 2.0, the application of social media}

Web 2.0 describes the current stage in the evolution of Internet usage. ${ }^{36}$ Today, the Internet runs heavily as a platform for user-generated content, interoperability, and usability. User-generated content is considered the "lifeblood" of applications more familiarly referred to as social

${ }^{29}$ Khawaja, Boddington, and Didham, Growing Ethnic Diversity, 46-47.

${ }^{30}$ Simon, Participatory Museum, 145.

${ }^{31}$ Black, "Developing Audiences," 134-142

32 Anne Fahy. "New Technologies for Museum Communication," in Museum, Media, Message, ed. Eilean HooperGreenhill. (London: Routledge, 1995), 82.

${ }^{33}$ Fahy, "New Technologies," 87.

${ }^{34}$ Fahy, "New Technologies," 94.

35 "Home," Museum of New Zealand Te Papa Tongarewa, accessed February 20, 2017, https://www.tepapa.govt.nz/

36 "What is Web 2.0," Tim O’Reilly, accessed May 29, 2016, http://www.oreilly.com/pub/a/web2/archive/what-isweb-20.html 
media. ${ }^{37}$ The distribution of texts, posts, images, audio and video are key features of applications like Facebook, Twitter, Instagram, and YouTube amongst a sea of other self-publishing platforms in the form of blogs and vlogs. According to the statistical data, Internet usage has grown $918.3 \%$ since $2000 .^{38}$ The Pew Institute, which collects information about Internet usage, started collecting information on American use of social media in 2005, which at that time was around 5\%. Today, that number has increased to around $70 \%{ }^{39}$ It also appears that the age gap between social media users is decreasing. While it is unsurprising that $90 \%$ of young people use the Internet, the number of users over the age of 65 more than tripled from $11 \%$ in 2010 to $35 \%$ in $2015 .^{40}$ The increased use of social media isn't just an American phenomenon though. Statista calculated that, the number of mobile phone users around the globe was 4.61 billion and Internet users surpassed 3.5 billion in $2016 .^{41}$ The increased efficiency of mobile technologies has had a direct effect on the increased use of social media. ${ }^{42}$ With a stable connection to Wi-Fi, one can use a smartphone or tablet to answer emails, Livestream in real time, and even monitor your cat while you're away from home. ${ }^{43}$ By far the largest benefit of social media is the ability to receive constant, up-to-date information. ${ }^{44}$ As generations of people use social media to engage with the rest of the world, it is crucial that museums develop strategic and sustained relationship building over social media platforms. ${ }^{45}$

${ }^{37}$ Jonathan A. Obar and Steven S. Wildman, "Social Media Definition and the Governance Challenge: An Introduction to the Special Issue," Telecommunications Policy, 39(9) (2015): 745-750. Quello Center Working Paper No. 2647377.

38 "World Internet Usage and Population Statistics," Internet World Statistics, accessed February 10, 2017, http://www.internetworldstats.com/stats.htm

39 "Social Media Fact Sheet," Pew Research Center: Internet \& Technology, accessed February 18, 2017, http://www.pewinternet.org/fact-sheet/social-media/

40 “Social Media Usage: 2005-2015,” Pew Research Center: Internet \& Technology, accessed January 27, 2017, http://www.pewinternet.org/2015/10/08/social-networking-usage-2005-2015/

41 "Number of Mobile Phone Users Worldwide from 2013 to 2019 (in billions)," Statista: The Statistics Portal, accessed October 17, 2016, https://www.statista.com/statistics/274774/forecast-of-mobile-phone-usersworldwide/; "Internet World Users by Language," Internet World Statistics, accessed October 17, 2016, http://www.internetworldstats.com/stats7.htm

${ }^{42}$ Jacob Poushter, "Smartphone Ownership and Internet Usage Continues to Climb in Emerging Economies," Pew Research Center: Global Attitudes \& Trends, February 22, 2016, accessed February 18, 2017, http://www.pewglobal.org/2016/02/22/smartphone-ownership-and-internet-usage-continues-to-climb-inemerging-economies/

43 "Home," Pet Cube, accessed February 20, 2017, https://petcube.com/

${ }^{44}$ Natalia Grincheva, "Cultural Diplomacy 2.0: Challenges and Opportunities in Museum International Practices," Museum \& Society, 11(1), (March 2013): 39-49. ISSN 1479-836.

${ }^{45}$ Angelina Russo, "Transformations in Cultural Communication: Social Media, Cultural Exchange, and Creative Connections," Curator: The Museum Journal 54 (2011), accessed May 8, 2016, doi:10.1111/j.21516952.2011.00095.x, 327; Jeffrey Gottfried and Elisa Shearer, "News Use Across Social Media Platforms 2016," 
Museums are, as Hein states, a "social instrument". 46 The role of museums, he believes, is to serve the public as educational institutions, providing visitors with the structure and platform to think reflectively and critically of the societies in which they live. ${ }^{47}$ In order to remain attractive to the shifting demographic and democratic communities that make up actual and potential visitors, museums must support "interaction with material in social contexts, starting with material familiar to the learner/visitor". ${ }^{48}$ This also requires museums to reflect upon the construction and context of the environments they create and maintain. Hein suggests museums "ask [themselves] whether [their] exhibitions and programs... address the issues that challenge visitors... about the society [they] live in."49

In the Participatory Museum approach, Simon discusses how implementing a participation approach improves a museum's ability to connect and communicate with new and diverse audiences. The three important elements she highlights are: an audience-centred approach; addressing the individual needs of visitors and potential visitors; and, lastly, the provision of tools for audiences to connect with each other and the museum. ${ }^{50}$ Simon is not alone in her argument that museums need to become more reflective and democratic, and transform the traditional approach of one-to-many to a many-to-many model. ${ }^{51}$ As noted previously, societies are changing. ${ }^{52}$ This brings us back to Fahy's interest in the Internet as a tool for connecting and networking on a larger scale.

In 2008, Russo explored the ways that museums were choosing to engage with audiences through social networks. She emphasises social media as a tool unlike other digital technology:

Pew Research Center: Journalism \& Media, May 26, 2016, accessed February 18, 2016, http://www.journalism. org/2016/05/26/news-use-across-social-media-platforms-2016/

${ }^{46}$ George E Hein, “'The Museum as a Social Instrument': A Democratic Conception of Museum Education," in Museum Gallery Interpretation and Material Culture, ed. Juliette Fritsch (New York: Routledge, 2011), 13.

${ }^{47}$ Hein, "Museum as a Social Instrument", 14-16.

${ }^{48}$ Hein, "Museum as a Social Instrument", 17.

${ }^{49}$ Hein, "Museum as a Social Instrument", 17-18.

${ }^{50}$ Simon, Participatory Museum, 35.

${ }^{51}$ Simon, Participatory Museum, 2; Russo, "Transformations," 331-333; Grincheva, "Cultural Diplomacy," 39-42; Lynch, Whose Cake...?, 20.

${ }^{52}$ Khawaja, Boddington, and Didham, Growing Ethnic Diversity, 4. 
It is the potential for a deeper interaction with community cultural content and knowledge that sets social media apart from other technology-mediated communication models through which museums work with audiences. ${ }^{53}$

Russo understands that museums need to incorporate social media as a strategic approach within communication, engagement, and knowledge sharing. To demonstrate how this can work, Russo explains how the British Museum's online programme, broadcast in 2010, called "A History of the World in 100 Objects" managed itself successfully. ${ }^{54}$ Through social media, the museum's collections were made available to the public. They created riveting podcasts and provided a platform where museums and individuals could share personal narratives, or stories of their own objects, online. It is this unique quality, social media's ability to "enhance the social memory of particular historical events" and objects, that really encouraged public interest. ${ }^{55}$ Simon explains that 'remembering together' is a crucial part of museum use of social media.

Remembering together is not a matter of marking out a collective memory that defines what everyone should remember in order to ground a specific communal ethos in a particular set of memories. Rather it is to study remembering together so as to open the possibility of a transformative critique of existing remembrance practices. 56

Despite knowing how social media platforms can enhance communal knowledge and improve engagement, many museums continue to convey messages to their audiences rather than developing knowledge with them. ${ }^{57}$

A recent study in Denmark examined the interactions between museums and audiences over Facebook. ${ }^{58}$ The objective of their study was to understand the values of engagement between museums and their online audiences. Overall, the study found museums used Facebook and took a 'message board' approach to inform audiences of activities in the museum. This is suitable for

\footnotetext{
53 Angelina Russo, Jerry Watkins, Lynda Kelly, and Sebastian Chan, "How Will Social Media Affect Museum Communication?" in Proceedings Nordic Digital Excellence in Museums (NODEM). (Oslo: Norway, 2006$), 22$.

${ }^{54}$ Russo, "Transformations," 327-46.

55 Roger I. Simon, "Remembering Together: Social Media and the formation of the Historical Present," in Heritage and Social Media: Understanding Heritage in a Participatory Culture, ed. Elisa Giaccardi (New York: Routledge, 2012), 89-106.

${ }^{56}$ Simon, "Remembering Together," 93.

${ }^{57}$ Elizabeth Crooke, “The 'Active Museum': How Concern with Community Transformed the Museum," in The International Handbooks of Museum Studies: Museum Practice, 1st edition, ed. Conal McCarthy (Chichester, West Sussex: John Wiley \& Sons, Ltd., 2015), 496; Lynch, Our Museum.

${ }^{58}$ Gronemann, Kristiansen and Drotner, "Mediated Co-construction," 174-190.
} 
audiences seeking a reason to visit the museum, however, it does very little to invite or engage with new audiences. ${ }^{59}$ The challenge, the researchers discovered, was in how museums broadcasted themselves. They compared the phrasing of posts and discovered that when museums responded to questions or asked for assistance, online engagement was plentiful. Just as with the $\mathrm{BBC}$ online project, the value for audiences and the institution was in the processes of meaning-making, knowledge production and social action. They compared this to the more common style of post, where the tone from the museum was authoritative and seemingly impenetrable, to find very few responses or interactions between institution and audience. The Denmark study acknowledges that there exist potential dangers lurking behind sticking with the traditional tones of authority in an age driven by social media.

The results are a number of unacknowledged tensions - between silence and communicative action, between genres pushing content and genres inviting contributions, between invitations to join knowledge formation and reinforcement of professional authority. ${ }^{60}$

They recommend museums make a conscientious effort to engage in "discursive coconstruction" with audiences over social media platforms.

Literature emphasising that museums use digital technologies is increasing. There is excitement to use social media as a platform to bring a larger audience closer to the stories around objects and history, however, there is a lack of literature that considers new and improved methods of engagement and communication. ${ }^{61}$ One reason for this may be the limited qualitative research on social media engagement practices for other industries.

In a recent article published by the Dominion Post, the author notes how the current environment of social media is risky for businesses. ${ }^{62}$ At the moment, the lines between a business and the

\footnotetext{
${ }^{59}$ Gronemann, Kristiansen and Drotner, "Mediated Co-construction," 184-185.

${ }^{60}$ Gronemann, Kristiansen and Drotner, "Mediated Co-construction," 187.

${ }^{61}$ Elisa Giaccardi, ed., Heritage and Social Media: Understanding Heritage in a Participatory Culture (New York: Routledge, 2012); Russo, "Transformations," 327-46; Gronemann, Kristiansen and Drotner, "Mediated Coconstruction."

${ }^{62}$ Susan Edmunds and Julie Iles. "Businesses Need Good Social Media Policies to Manage Risk," Stuff News, February 20, 2017, accessed February 20, 2017, http://www.stuff.co.nz/business/89551636/businesses-need-goodsocial-media-policies-to-manage-risk
} 
behaviours of individual employees can become quite blurred. ${ }^{63}$ The threat of employees' personal content (videos, images, stories) going "viral" over social media has many companies quite concerned as any negative publicity can be linked back to the business and grow quickly out of hand. In 2017, opportunities to share information and ideas, and protest over social applications, like Twitter and Facebook, often use the \# symbol. The \# became iconic in gaining the attention of social media users during political unrest in the Middle East remembered as the "Arab Spring" ${ }^{64}$ The democratic uprisings that took place in several Arabic countries in 2011 were credited to the mobilisation efforts taken over social media using the \#. Since then, the \# has been used in many movements for social justice, including the Occupy movement, \#bringbackourgirls, and \#blacklivesmatter. ${ }^{65}$ Even at the time of writing this dissertation, my social media platforms are ablaze with photos, posts, and tweets using the \# to unite ideas, jokes, and information.

Perhaps one of the most daunting challenges to $21^{\text {st }}$ century museums is appealing to a community that is becoming more diverse and globally aware through the Internet. As the demographics of populations change and massive amounts of information infiltrate our lives through computer screens and mobile devices, museums must consider how they present themselves and act online. While it is clear that museums know to engage with audiences online, the Gronemann et al. study shows us that an infrastructure of co-constructive engagement is lacking. How can or should museums conduct themselves in this internet-driven Age of Protest? To answer this question, I chose to research the dialogic content created over Facebook during the Kimono Wednesdays protests. I focused on how the public used Facebook during Kimono Wednesdays to discuss their opinions about the protest. I also looked into the MFA's reaction to

\footnotetext{
${ }^{63}$ Nicole B Ellison et al., "Negotiating Privacy Concerns and Social Capital Needs in a Social Media Environment," in Privacy Online: Perspectives on Privacy and Self-Disclosure in the Social Web, ed. Sabine Trepte and Leonard Reinecke (Berlin: Springer-Verlag Berlin Heidelberg, 2011), 19-32; “Social Media Fact Sheet," Pew Research Center.

${ }^{64}$ Philip N. Howard and Muzammil M. Hussain, Democracy's Fourth Wave?: Digital Media and the Arab Spring (New York: Oxford University Press, 2013).

${ }^{65}$ R. Effing, J. van Hillegersberg, and T. Huibers, "Social Media and Political Participation: Are Facebook, Twitter and YouTube Democratizing Our Political Systems?" in Electronic Participation, ePart 2011. Lecture Notes in Computer Science, vol 6847, ed. E. Tambouris, A. Macintosh, and H. de Bruijn (Berlin: Springer-Verlag Berlin Heidelberg, 2011); "Social Media Update 2016," Pew Research Center: Internet \& Technology, accessed February 20, 2017, http://www.pewinternet.org/2016/11/11/social-media-update-2016/
} 
the protesters through an analysis of the online content created on their website and in a symposium, Kimono Wednesdays: A Conversation, uploaded to YouTube.

\section{Research design}

In order to answer the question "How are museum audiences using social media in the Age of Protest?", this research examined a single case study, Kimono Wednesdays. To understand the main question, I created sub-questions that reviewed the protests and dialogic content created over social media. These sub-questions explored how the MFA's audience discussed Claude Monet, Flirting with the Exotic, and the Kimono Wednesdays events on Facebook and elsewhere online. I also reviewed the Museum's online behaviour. I chose to use a discovery-led case study approach, in which I applied an in-depth investigation of a single incident as it developed online through social media applications. My main source of information was an online excavation of blogs, online news journals, Instagram, Twitter, Tumblr, and Facebook. This method was used to highlight how social media provides museum audiences with the power to generate discussions around museum practices, as well as the diversity of emotional content on the topic of museum cultural narratives.

This approach was influenced by Gronemann et al in their research on "Mediated CoConstruction of Museums and Audiences on Facebook". ${ }^{66}$ The Danish researchers collected and analysed the dialogic activity on the Facebook pages of nine Danish museums. The purpose of this approach was to examine "how processes of co-construction are established, upheld, modified and developed". 67

As discussed by Fell and Russo, the literature on museums' use of social media is limited. ${ }^{68}$ To my knowledge, research and analysis of museums using social media as a tool to engage coconstructively with audiences is relatively new. Instead, research into museums' use of social media focuses on institutionally driven content and the various models of distribution, and

\footnotetext{
${ }^{66}$ Gronemann, Kristiansen and Drotner, "Mediated Co-construction," 174.

${ }^{67}$ Gronemann, Kristiansen and Drotner, "Mediated Co-construction," 179.

${ }^{68}$ Fell, "Going Social"; Russo et al, "How Will Social Media...?".
} 
interaction/engagement from an authoritative model ${ }^{69}$ It is the intention of this dissertation to provide useful information on and around a topic that future researchers in the museum and heritage sector can build upon. The decision to focus on a single case study was made due to the need to meet time constraints and to provide sufficient space to examine the finer details of the connections and interactions between the museum and breadth of audience perspectives. Considering previous literature written on participation, co-construction, and use of online applications, I have attempted to produce a clear but multi-dimensional perspective of the Kimono Wednesdays controversy at the MFA in June and July of 2015.

\section{Parameters of the research}

A case-study approach focuses on an isolated phenomenon in order to produce an in-depth study. Denscombe explains that this form of research "investigate[s] an issue in depth and provide[s] an explanation that can cope with the complexity and subtlety of real life situations". ${ }^{70}$ The parameters of the Kimono Wednesday controversy began on 20 July 2015 and officially concluded in March of 2016. I began with a discovery-led method of case-study research. This process, which emphasises the exploration of the setting of an event, processes, and relationships, allowed me to isolate the Kimono Wednesdays controversy in a particular window of time. ${ }^{71}$ Through this I was able to focus on various details, including discussions and actions that took place or were reported online. During this process, as suggested by Yin and Denscombe, I focused on questions of 'why' and 'how' the phenomenon occurred and less on the outcome. ${ }^{72}$ Given the limitations of time and resources, this method seemed to be the most achievable option. However, given more time, other processes for collecting data could have included interviews with the MFA staff and online commenters, analysis of social media protocols and behaviour after the set parameters of time, a larger selection of case studies, or trialling several theories over social media. However, the following in-depth case study can be

\footnotetext{
${ }^{69}$ Fell, "Going Social”; Russo et al, "How Will Social Media...?”; Gronemann, Kristiansen and Drotner, "Mediated Co-construction"; Giaccardi, Heritage and Social Media.

${ }^{70}$ Martyn Denscombe, The Good Research Guide: For Small-Scale Social Research Projects (New York: McGrawHill Education, 2013), 55.

${ }^{71}$ Denscombe, Good Research Guide, 55.

${ }^{72}$ Denscombe, Good Research Guide, 53; Robert K. Yin, Case Study Research: Design and Methods, 5th edition (Thousand Oaks, CA: Sage Publications, Inc., 2014), 10-11.
} 
used to assist future research on the topic of museums' engagement with audiences through social media.

\section{Challenges}

There were some issues around accessibility and the collection of data. Similar to other forms of document-based evidence research, irretrievability, biased selection, biased authorship and access to documents are a weakness in this research. ${ }^{73}$ Given all of the content is online-based, there were no physical restrictions with exception of situations when internet was not accessible or technology broke or failed. There were internet-based challenges; these occurred when resources changed or content was edited. For example, individuals creating a page on Facebook have the freedom to remove and restrict content at their will. There were also pages and documents that have been deleted or expired.

In addition, there is a uniquely structural Internet-based bias, which in many other situations is helpful to users online. Machine learning refers to artificial intelligence where computers 'think' by themselves. That is, "having computers act without having to be specifically programmed". 74 This can be beneficial to the advancement of society in many ways: developing self-driving cars, uncovering new aspects of the human genome, even analysing the influences of artists' works on each other. ${ }^{75}$ In terms of research, however, machine learning can actually work against the researcher. ${ }^{76}$ An informatics page from Google explains "How Search Works". 77 There are algorithms to break down the content typed into the search box, a selection process ranking the most relevant content, safeguards, translation and categorisation of results. While this can be

\footnotetext{
${ }^{73}$ Yin, Case Study Research, 106.

74 Stanford University, "Machine Learning," Coursera online course, accessed November 29, 2016 , https://www.coursera.org/learn/machine-learning

75 “Self-Driving Car [Waymo, as of December 2016]," Google, accessed 29 November 2016, https://www.google.com/selfdrivingcar/; Vinod Khosla, "Do We Need Doctors or Algorithms?” TechCrunch.com, January 10, 2012, accessed January 27, 2017, https://techcrunch.com/2012/01/10/doctors-or-algorithms/; The Physics arXiv Blog, "When a Machine Learning Algorithm Studied Fine Art Paintings, It Saw Things Art Historians Had Never Noticed," Medium.com, accessed February 27, 2017, https://medium.com/the-physicsarxiv-blog/when-a-machine-learning-algorithm-studied-fine-art-paintings-it-saw-things-art-historians-had-neverb8e4e7bf7d3e\#.rt4qo9mgm

${ }^{76}$ William L. Hosch, “Machine Learning,” Encyclopaedia Britannica Online Academic Edition, accessed January 7 , 2017, https://www.britannica.com/technology/machine-learning

77 "How Search Works," Google, accessed February 27, 2017, http://www.google.co.nz/insidesearch/howsearch works/thestory/
} 
helpful in limiting irrelevant content showing up in the results, it is difficult to be certain that crucial information has not been excluded or missed.

As mentioned above, I have used data collected only from online social media platforms. Given that content can be changed or removed altogether from the Internet, I have kept electronic and physical copies of the data collected and will continue to do so until the University has approved this thesis. This has also helped to keep a timeline of events and track changes in search results over the time I collected data.

Yin also warns that, when using data collected on social media, the researcher should "use the information... with a highly sceptical view, for example, being aware that claims about the authorship, places or times attributable to material may not be fully accurate". ${ }^{78}$

While I was aware of this from the beginning of the project, at times it was challenging to evaluate the truthfulness of some content. It was important to set in place guidelines, which helped to decipher truth from fiction, opinion from fact. In this dissertation, I present this research in a manner that attempts to fairly express opinions and information.

\section{Summary}

This Introduction has provided background and rationale that acts as a framework for reading the remainder of this dissertation. I have built upon my argument, presented the research aims and objectives, and detailed the research design I employed. Chapter 1 will be the introduction of the case study of the Kimono Wednesdays protests at the Museum of Fine Arts, Boston.

\footnotetext{
${ }^{78}$ Yin, Case Study Research, 129.
} 


\section{Chapter 1}

Setting for the Case Study

\section{Claude Monet, Flirting with the Exotic, and the Kimono Wednesday events}

This chapter discusses the events that led up to and evolved around the Kimono Wednesdays protests at the Museum of Fine Arts, Boston (MFA) in 2015. I have divided the chapter into three parts; the first is a broad overview on the history of the MFA, and the acquisition, history, and conservation of La Japonaise, by Claude Monet. Following this, I discuss the La Japonaise workshop (ラ・ジャポネースワークショップ), which was developed when the painting was on exhibit in Japan. The last section discusses the return of La Japonaise to the MFA, the Museum's marketing over social media for a 'try-on' event, and recollections of the protests held in Gallery 255.

Introducing the case study

The MFA opened its doors to the public on the American Centennial, 4 July 1876. Along with its collection, the museum also established an art school currently known as The School of the Museum of Fine Arts at Tufts. The school promotes themselves as the only art school in the U.S. that is both a research facility and associated with a national art museum. ${ }^{1}$ In 1909, the MFA moved to its current location on Huntington Ave. Since then, the MFA's collection and building has grown extensively, with several new wings added in the last quarter century. Currently, the museum is believed to be the United States' fourth largest museum. ${ }^{2}$ In 1999, in an unprecedented effort to globalise the institution, the MFA began a 20-year partnership by opening a sister museum in Nagoya, Japan. ${ }^{3}$ It is the goal of the Nagoya/Boston Museum of Fine Arts to "enable [the] people in Japan not only to enjoy great masterpieces, but also to appreciate art from culture and periods that until now has had little exposure in Japan". 4 The collaboration

\footnotetext{
1 “About the MFA," Museum of Fine Arts, Boston, accessed January 22, 2017, www.mfa.org/about

2 Wikipedia contributors, "List of Largest Art Museums," Wikipedia, The Free Encyclopedia, accessed January 22, 2017, https://en.wikipedia.org/wiki/List_of_largest_art_museums

3 “The Museum Year 2009: Director's Message," Museum of Fine Arts, Boston, accessed January 22, 2017, www.mfa.org/annual-report-2009/director.html

4 “About Us," Nagoya/Boston Museum of Fine Arts, accessed January 22, 2017, www.nagoyaboston.or.jp/english/about/outline.html
} 
has allowed curators from both institutions to study, research, and discuss exhibitions and "serve as an important model for artistic and cultural exchange between the United States and Japan". 5

In March of 2013, the MFA began a large-scale conservation effort on a piece in their collection, Claude Monet's La Japonaise. The Museum purchased the painting in 1956 for $\$ 45,000$ from Duveen Bros, Inc. ${ }^{6}$ The Museum's website explains that the painting, dated to 1876, was originally called Japonerie, after a recently coined French word that described Western works of art that imitated Japanese artwork or objects. ${ }^{7}$ Monet, the website explains, was a fan and avid collector of Japanese artwork, particularly woodprints. It is believed that his collection also influenced his work. When discussing La Japonaise, the webpage theorises that Monet, aware of the popularity of artwork depicting Western women posing suggestively in Japanese kimono, and largely in debt at the time, created this painting in hopes of selling it to a wealthy buyer.

La Japonaise is a depiction of Monet's first wife, Camille, standing on top of tatami mat dressed in an elaborately embroidered red kimono, called an uchikake (打掛 : a type of heavily padded coat to be worn over kimono in colder weather for special occasions by the social elite and entertainers). Naturally a brunette, Camille also wears a blonde wig while posing with a kind of come-hither look, holding a sensu (扇子 : foldable paper fan) in the colours of the French flag, with a scattered assortment of uchiwa (団扇 : handheld fan) on the wall and floor around her.

The piece is significant for several reasons; first, it is the artist's last large-scale portrait and one of Monet's earlier paintings exploring the use of Japanese aesthetics. Also, La Japonaise has both mesmerised and confused audiences since its debut. Gedo discusses the painting's whimsical, slightly erotic, and surreal blend of Western and Japanese aesthetics, bold colours, and brushwork. ${ }^{8}$ At the unveiling in 1876 , critics commented on the teasingly provocative pose

\footnotetext{
5 “Nagoya/Boston Museum of Fine Arts," Museum of Fine Arts, Boston, accessed January 23, 2017, http://www.mfa.org/exhibitions/mfa-on-tour/Nagoya

6 "La Japonaise (Camille Monet in Japanese Costume)," Museum of Fine Arts, Boston, accessed January 23, 2017, www.mfa.org/collections/object/la-japonaise-camille-monet-in-japanese-costume-33556

7 “Conservation in Action: La Japonaise, March 2013," Museum of Fine Arts, Boston, accessed January 27, 2017, http://www.mfa.org/collections/conservation/conservation-in-action/la-japonaise/march-2013

${ }^{8}$ Mary Mathews Gedo, Monet and His Muse: Camille Monet in the Artist's Life (Chicago: University of Chicago Press, 2010), 176.
} 
of the woman, in her half-turned stance, the fan appearing to wave flirtatiously by her face. As the viewers' eyes shift down towards the bottom of the garment, a ferocious 'samurai' is already unsheathing his sword, as if to ward off any lusty intent. ${ }^{9}$

Monet, whose later work was inspired by his own collection of Japanese art and his Japanese inspired garden, later referred to this painting as 'saleté' (dirt or junk). ${ }^{10}$ Though it is uncertain why he would refer to a painting of his wife in such a manner, Gedo explains how the subtle, but distinctly provocative, posture and facial expression of the figure in the painting are unique:

Monet never depicted the female nude, even his private sketchbooks are innocent... In creating La Japonaise, Monet required Camille to assume a persona apparently alien to her real-life personality... [the painting] represents Mme. Monet as a rather frivolous, flirtatious, bewigged European woman pretending to be a Japanese geisha or courtesan. ${ }^{11}$

Sometime after the MFA acquired La Japonaise, conservators took notice of areas where the paint had begun to crack and peel away from the canvas. Previous efforts, in 1972, to conserve the artwork with a wax-resin adhesive had neglected the issue of cracking paint and instead, where the adhesive had been applied, created an irregular fuzzy look to the painting. While the MFA's conservators worked on the delicate task of restoring the painting by removing the waxresin and repairing the cracks, visitors were permitted to observe the process though a glassed wall of the conservators' studio. Upon completion, La Japonaise, among a collection of 150 other objects, was sent on an international travelling exhibition.

\footnotetext{
${ }^{9}$ Gedo, Monet and His Muse, 167.

${ }^{10}$ Gedo, Monet and His Muse, 167.

${ }^{11}$ Gedo, Monet and His Muse, 175-176.
} 
To view images please refer to the physical copy located in the VUW Library or the Art History and Classics department. Information on the images are also located after the Glossary on page 69
To view images please refer to the physical copy located in the VUW Library or the Art History and Classics department. Information on the images are also located after the Glossary on page 69

Figure 1 (left): Claude Monet's La Japonaise, painted in 1876. Figure 2 (right): A photo posted on the MFA's website while the painting underwent conservation in 2013, in a laboratory with a glass wall that allowed visitors to watch 'conservation in action.'

\section{A grand tour, La Japonaise goes to Japan}

The exhibition, inspired by Helen Burnham's publication of the same name, was titled Looking East: Western Artists and the Allure of Japan. ${ }^{12}$ The tour travelled through three countries: the first stop was Tennessee, in the U.S.; it then travelled to three museums in Japan before returning to North America, where the exhibition was sent to Canada and finally, returned to San Francisco, California. ${ }^{13}$ The collection exhibited 130-150 artworks and objects imported into Europe from Japan in the mid to late $19^{\text {th }}$ century. ${ }^{14}$ The exhibition explored the theme of a "radical renewal of the arts" under Japonisme, a French term coined by Philippe Burty.

Japonisme is affixed to European art and culture predominantly from the 1860-70s when a large

\footnotetext{
12 "Publication," Museum of Fine Arts, Boston, accessed August 8, 2016, http://www.mfa.org/collections/ publications/looking-east-0

13 "Looking East: Western Artists and the Allure of Japan," Frist Center for the Visual Arts, accessed January 28, 2017, http://fristcenter.org/calendar/detail/looking-east-western-art-and-the-allure-of-japan

14 "Looking East: Western Artists and the Allure of Japan," Musée National Des Beaux-Arts du Québec, accessed January 28, 2017, https://www.mnbaq.org/en/exhibition/looking-east-1227; “Looking East,” Frist Center.
} 
number of Japanese goods were being exported around the world. ${ }^{15}$ The cause of this heavy influx was due to the arrival of black ships (黒船). ${ }^{16}$ Shortly after the 1850 s, a treaty to engage in Western trade was signed. ${ }^{17}$

For its Japan tour, the exhibition was sponsored in part by the Japanese national broadcasting company, NHK. Excited to celebrate the successful restoration of La Japonaise (ラ・ジャポネー ㅈ), NHK funded the famed Kyoto-based theatre production company, Takarakuza Stage Co., to produce two replicas of the uchikake worn by Camille in the painting; one adult-size and one child-size. ${ }^{18}$ In Japan, ラ・ジャポネース was the star attraction of the exhibition. ${ }^{19}$ To encourage visitor engagement, limited workshops (ワークショップ) were sold at each of the touring locations. Ticket holders attended special photoshoot-esque sessions where attendees dressed in the uchikake, had their hair done up or wore a blonde wig, and stood on a recreated stage just like the one in Monet's painting. ${ }^{20}$ Photos shared on Instagram from these ワークショップ show an enthusiastic visitor attendance made up mostly of women. ${ }^{21}$

For general audiences who didn't attend the special event, a cut-out photo board, placed outside the gallery space, allowed visitors to replace Camille's face with their own and have their picture taken. The Nagoya/Boston Museum of Fine Arts also included a special event for the visually impaired, providing a hands-on experience with a 3D model of the painting and the replica uchikake and fans, and a tour of the exhibit during which the painting was described to them. In

15 “Looking East,” Musée National Des Beaux-Arts du Québec.

16 黒船 (kurofune or "black ships”) is a Japanese reference to Western vessels that arrived in Japan in the 1850s and broke the country’s 200 years of isolation. 昭甫 神徳，“日本開国－異文化交錯の劇空間,”人文学部紀要 40 (2004): 85-167.

17 "Commodore Perry and Japan (1853-1854)," Asia for Educators, Columbia University, accessed February 27, 2017, http://afe.easia.columbia.edu/special/japan_1750_perry.htm; "Looking East," Frist Center; "Looking East," Musée National Des Beaux-Arts du Québec.

${ }^{18}$ Japanese-American in Boston, "Monet's La Japonaise Kimono Wednesdays at the MFA,” blog post, July 7, 2015 (4:20PM), modified July 13, 2015, accessed January 27, 2017, http://japaneseamericaninboston.blogspot.co.nz/ 2015/07/monets-la-japonaise-kimono-wednesdays.html; Wikipedia contributors, "Takarazuka Revue," Wikipedia, The Free Encyclopedia, accessed January 28, 2017, https://en.wikipedia.org/wiki/Takarazuka_Revue

19 "Nagoya/Boston Museum of Fine Arts: History of Exhibitions," Museum of Fine Arts, Boston, accessed January 23, 2017, www.mfa.org/news/nagoya-exhibition-history

20 “あなたも「ラ・ジャポネーズ」になれる！世田谷美術館でワークショップ開催 [You can be 'La Japonais’! Workshop held at the Setagaya Art Museum],”せたがや Setagaya City, accessed January 29, 2017, http://www.city.setagaya.lg.jp/kurashi/107/159/778/h26/d00134505.html

21 “あなたも「ラ・ジャポネーズ」になれる ! [You can be ‘La Japonais’!].” 
addition, souvenirs like bookmarks and postcards of La Japonaise were sold in the museum gift shops, and the Setagaya Art Museum in Tokyo sold limited-edition souvenirs of the popular character mascot, Rilakkuma, dressed in a red kimono.

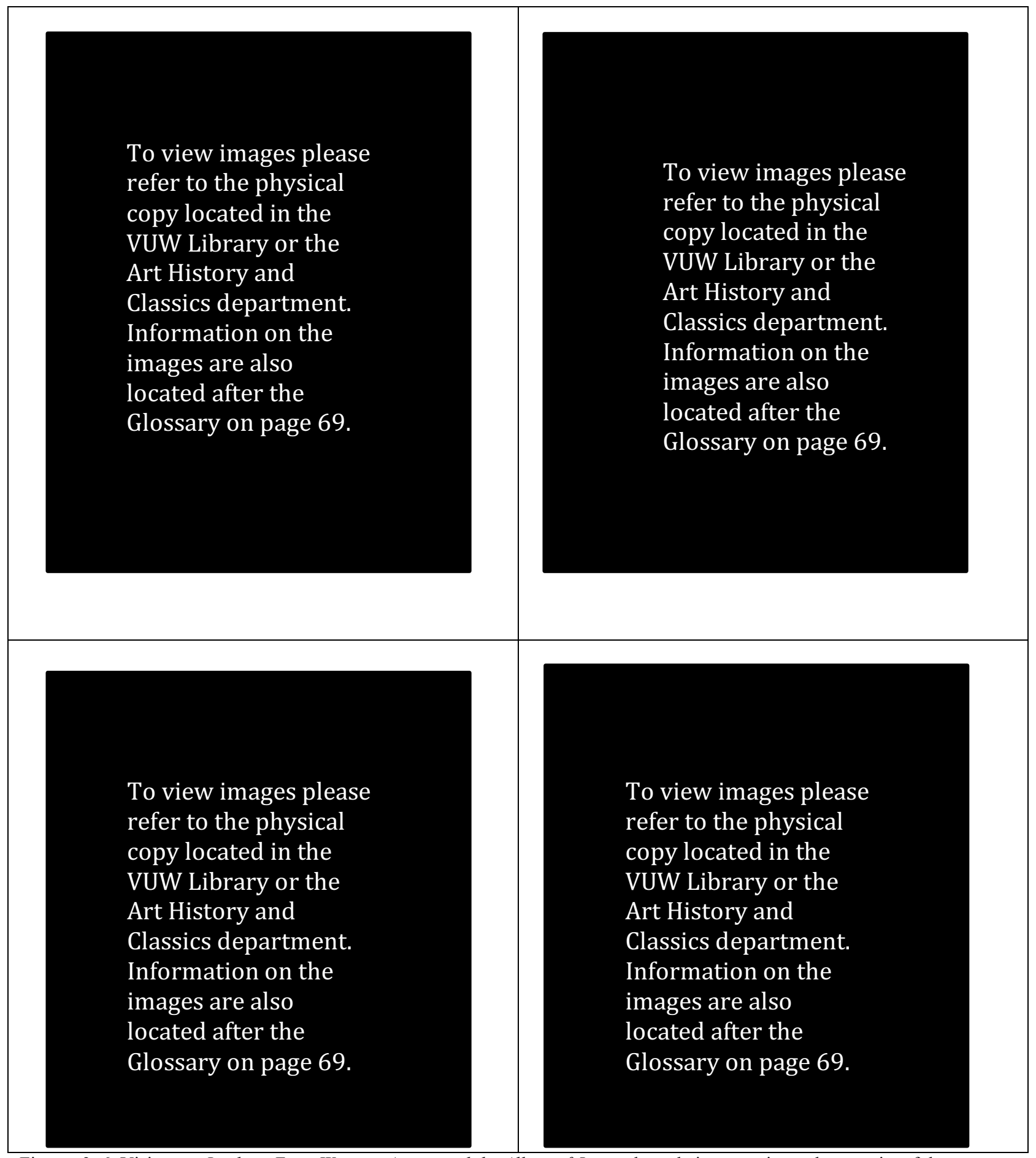

Figures 3-6. Visitors to Looking East: Western Artists and the Allure of Japan share their memories and souvenirs of the exhibition on Instagram. 
In scrolling through images posted to Instagram, it appears that the exhibition and ワークショッ $7^{\circ}$ in Japan were well received. Visitors who shared their experiences online show off their souvenirs and their memories of pretending to be Camille Monet dressed in the uchikake. Intrigued at the popularity of the events in Japan, the MFA asked NHK for the uchikake, with the intent to hold a similar event, allowing visitors to dress up in Camille's kimono. NHK acquiesced by gifting the uchikake to the MFA. ${ }^{22}$

La Japonaise returns to Boston, the start of Kimono Wednesdays controversy

In June of 2015, the Looking East: Western Artists and the Allure of Japan exhibition, moved onto its next international destination, Musée National de Beaux-Arts du Québec, but without $L a$ Japonaise, which returned to Boston, accompanied by the two replica uchikake. ${ }^{23}$ The MFA had organised several events as part of a farewell send-off for the leaving Director, Malcolm Rogers. These included Kimono Wednesdays, similar to the ワークショップ held in Japan, and accompanied by a lecture series using the uchikake from NHK. The Museum advertised the events as Kimono Wednesdays and it encouraged visitors to "Channel your inner Camille \#Monet..." as shown in the picture below.

\footnotetext{
${ }^{22}$ Museum of Fine Arts, Boston, Kimono Wednesdays: A Conversation, YouTube video, 2:03:30, posted by "Museum of Fine Arts, Boston," February 12, 2016, https://www.youtube.com/watch?v=_M0m8qaXrus\&t=3475s 23 "Looking East," Musée National Des Beaux-Arts du Québec.
} 
To view images please refer to the physical copy located in the VUW Library or the Art History and Classics department. Information on the images is also located after the Glossary on page 69 .

Figure 7. "Channel your inner Camille Monet and pose wearing a silk kimono just like hers in front of the portrait painted by her husband. Our favourite photos will be featured on Facebook and Instagram!"

In addition, 15-minute lectures titled Claude Monet: Flirting with the Exotic provided information about Monet and his wife, Camille, the muse who posed for the painting. ${ }^{24}$ The Museum first advertised the event in their membership newsletter and on their website. Later, on 20 June 2015, posts over social media on Instagram, Facebook, and Twitter provided wider and more public awareness of the event.

\section{A protest erupts in the gallery: The beginning of@DecolonizeOM}

Though several questions remain unanswered as to how and when the protests over social media began, negative comments are noticeable on the Facebook post around 24 June $2015 .^{25}$ In the initial days of the protest, some people mobilised on Facebook to create a group, "Stand Against

\footnotetext{
24 Japanese-American in Boston, "Monet's La Japonaise Kimono Wednesdays at the MFA."

${ }^{25}$ Comments on Museum of Fine Arts, Boston's Facebook page, accessed 7 July 2016, https://www.facebook.com/pg/mfaboston/posts/
} 
Yellow Face @ the MFA". ${ }^{26}$ Members of the group claimed to be the organisers of the in-gallery protests, held in front of La Japonaise. Later, the group took down the Facebook page and rebranded themselves on Tumblr, Facebook, and Twitter as "Decolonize Our Museums" (@) DecolonizeOM). ${ }^{27}$

On their social media pages, DOM published the reasoning behind the Kimono Wednesdays protests in a long document including a list of demands directed at the Museum. ${ }^{28}$ In the document, DOM reprimands the MFA for putting on an event that exposed a fundamental bias of Western Expansionist ideas on Orientalism that continue to affect the Asian American and Pacific Islander (AAPI) community. The signers of the document, who acknowledge that they are not Japanese or Japanese-American, also articulate that their concerns are not Japanesecentric but focus on the communities of Asian and Asian-Americans as a holistic group. In their critique of the MFA, they contest the advertising, the educational information provided to audience and staff, and the response, or lack thereof, from the MFA.

Regarding advertising, DOM took umbrage at the word choices of exotic and flirting, in the invitation to dress up as a white woman sexualised in foreign dress. Another frustration was, perhaps, the casual, kitschy attempt to alliterate Kimono with Wednesdays:

LANGUAGE The way the MFA chose to go about advertising this event via social media (Facebook particularly - how it first came to our attention) had familiar Orientalist markings that upon actually experiencing the on-site curation demonstrated an all-too familiar uncritical regurgitation of Orientalist framing that often occurs when institutions do not use their considerable resources to flesh out the acceptability of various PR campaigns, particularly ones referencing historically othered cultures, given the U.S.' own problematic complicity in othering whole peoples abroad and great populations of their own citizenry here.

ORIENTALIST MARKINGS IN THE ADVERTISING The talk title "Flirting with the Exotic" is blatantly inappropriate. The word choice "Channel your inner

\footnotetext{
${ }^{26}$ Franklin Einspruch, "Boston Kimono Alarms Culture Crusaders," The Federalist, July 10, 2015, accessed January 7, 2017, http://thefederalist.com/2015/07/10/boston-kimono-alarms-culture-crusaders/

${ }^{27}$ Decolonize Our Museums, Tumblr page, accessed January 30, 2017, http://decolonizeourmuseums.tumblr.com

${ }^{28}$ Decolonize Our Museums, "Full Response to MFA 'Kimono Wednesdays' + 'Flirting with the Exotic'," Tumblr post, July 29, 2015, accessed 30 January 2017, http://decolonizeourmuseums.tumblr.com/post/125348836324/fullresponse-to-mfa-kimono-Wednesdays
} 
Camille" centres a white European woman without acknowledging what we today call Orientalism or the [J]aponisme of the time. Additionally, language such as "Pose wearing a silk kimono just like hers" reduces the experience of understanding the painting to dress-up.

DOM criticised the educational 15-minute lectures as historically inaccurate and failing to include Monet's own disregard for the painting and his disapproval of the Japonisme fad at the time.

Monet's painting by the MFA's own wording was "a witty comment on the current Paris fad for all things Japanese". By "witty comment" we are meant to understand that the painting is supposed to be a satirical jab at the absurdity of Europeans [sic] fascination with "all things Japanese". ... why not provide a discussion on the historical context and criticality about the 1870 s obsessions?

Just before their list of demands, DOM frustratedly express that many of the group (they claim in an earlier section, that they didn't know each other at the time) raised questions and concerns with the MFA but did not receive a response.

LACK OF IMMEDIATE RESPONSE What is quite telling is that this MFA campaign was met with outcry from the public, checking the Orientalist framing of the event almost immediately upon its launch on social media, and yet, the institution chose to go forward with the event. The museum's dismissal of public opinion shows the absolutely unapologetic stance many cultural institutions first take when alerted to wrongdoing. Further, though we personally solicited a dialogue on the morning of the launch event (we left a voicemail with the PR department and noted so on the Facebook post), there has been no attempt by the MFA to address us as members of the public, either by phone, Twitter, or via our subsequent Facebook event page...

Overall, the document is quite telling, in that the frustrations of the protesters over the Kimono Wednesdays become a platform to discuss a much larger context of the sexualised stereotyping of Asian women that occurs in America. Based on this, it is entirely possible that the protests at the MFA had less to do with the institution or event and were, instead, intended to address issues of implicit bias happening everywhere. ${ }^{29}$ At the end of the document, there is a "List of Demands". This appears to require that the MFA engage in more critical analysis with art, in the narrative of the art and the perceptions of history that accompany it. Their demands include that the MFA make a public apology, stop the Kimono Wednesdays events, change the context in the

\footnotetext{
${ }^{29}$ Implicit bias refers to thoughts, feelings, attitudes, and preferences based on stereotypes that people place on others unconsciously. See "Implicit Bias," Perception Institute, accessed December 6, 2016, www.perception. org/research/implicit-bias/
} 
discussions of Claude Monet: Flirting with the Exotic, and provide more informative placards regarding the acquisition of art and objects on display in the institution.

The Kimono Wednesdays protests grew over a short period of time, both online and inside the gallery. News of the situation even reached Japan. ${ }^{30}$ Awareness of the protests grew and, in the third week of the event, a group of counter-protesters, made up of Japanese, Japanese-Americans and others, organised in the gallery to confront the protesters. ${ }^{31}$ As protests and counter-protests escalated both online and inside the gallery, the MFA, which had been mostly silent, took action. Many online articles and comments over social media reported that the MFA had cancelled the Kimono Wednesdays. ${ }^{32}$ This was not true, but the MFA did change the event. In a public apology published on the Museum's website, it is clearly stated that the kimono events would continue but visitors would be prohibited from trying on the uchikake. However, they were still allowed the chance to touch and feel the garment. ${ }^{33}$ The MFA also acknowledged their own cultural insensitivity in the handling of the events and advised that the original 15-minute lectures, now retitled Spotlight Talks, would engage more deeply with the issues around the history of French Impressionism and the influence of Japonisme.

...The kimonos will now be on display in the Impressionist gallery every Wednesday evening in July for visitors to touch and engage with, but not to try on. This allows the MFA to continue to achieve the program's goal of offering an interactive experience with the kimonos - understanding their weight and size, and appreciating the embroidery, material, and narrative composition. We will also increase the number of Spotlight Talks presented by MFA educators, to take place every Wednesday evening in July in conjunction with the display of the kimonos. The talks provide context on French Impressionism, "Japonisme," and the historical background of the painting, as well as an opportunity to engage in culturally sensitive discourse. We apologize for offending any visitors, and welcome everyone to participate in these programs...

\footnotetext{
${ }^{30}$ Yuco, “ボストン美術館の「ラ・ジャポネーズ論争」[Boston Museum’s 'La Japonaise Controversy'],” blog post, July 10, 2015 (22:03PM), accessed January 23, 2017, https://note.mu/yuco/n/n30a6f37c7fb0

31 Japanese-American in Boston, "Part 2: Protest and Counterprotest @ July 15th Kimono Wednesday," blog post, July 17, 2015 (2:38AM), accessed February 27, 2017, http://japaneseamericaninboston.blogspot.co.nz/2015/07/ part-2-protest-and-counterprotest-july.html

32 Associated Press, "Mainland Art Museum Cancels 'Kimono Wednesdays' After Uproar," Honolulu Star Advertiser, July 7, 2015, accessed March 29, 2016, http://www.staradvertiser.com/2015/07/07/breakingnews/mainland-art-museum-cancels-kimono-wednesdays-after-uproar/

33 "Press: July 2015," Museum of Fine Arts, Boston.
} 
While it seemed that the Museum's decision to alter the event was intended to alleviate the brewing tension, it only seem to exacerbate the online and in-gallery discourse. Keiko, a blogger at Japanese American in Boston, wrote extensively on her experience with the Kimono Wednesdays event, and discourse with the protesters, counter-protesters, and the MFA. ${ }^{34}$ When she approached museum staff regarding the protests and why they were allowed to continue in the museum, she learned the MFA had never encountered a situation like this before.

I asked MFA staff a question ... why are the protesters permitted to be in the gallery? They said that ordinarily large protests are not permitted in the building or even on MFA grounds. ... in this case, the protest started really small (3 people the first week according to the staff) and they didn't feel protesters were being disruptive. As a museum, they want people to talk about the art and since the protest sparked dialogue they decided to let them stay. ...It is not illegal to protest or to argue with people. Update 7/26/15: I found out last week that the MFA didn't have a policy to handle a situation like this since it had never happened before. ...

It is quite understandable that the MFA was not prepared for the backlash that unfurled during Kimono Wednesdays. As I discussed in the literature review, controversy and protest has occurred in museums before, but the type of emotional, moral mobilisation that occurred at the MFA was a new concept in the Web 2.0 era.

\section{Summary}

In 2013, the MFA began conservation on La Japonaise, an unusual painting by Claude Monet of his first wife, Camille, posing provocatively in an elaborate red uchikake. To celebrate the successful restoration and new exhibition, Looking East: Western Artists and the Allure of Japan, NHK, a sponsor of the Japanese section of the tour, decided to have two replica uchikake created for a special try-on workshop. The workshop and painting were well received in Japan. However, a similar event organised by the MFA, and marketed over social media, received backlash both online and within the gallery. As public attention and tempers grew, the MFA decided to change the programme.

\footnotetext{
34 Japanese-American in Boston, "Part 2: Protest and Counterprotest."
} 
In this chapter, I have provided context for the Kimono Wednesdays protest. In Chapter 2, I discuss the variety of conversations that transpired over Facebook and explore how these discussions shaped the impressions of the protesters' message. 


\section{Chapter 2}

Facebook post and comment analysis

\section{Facebook: the $21^{\text {st }}$ century's social frontier}

Chapter 1 explained the events around the Kimono Wednesdays protests. Although originating and enjoying success in Japan, this "dress up in kimono" event received mixed reviews from the MFA's audience. In particular, members within the Asian-American community were strongly opposed to the event. Protesters argued strongly that the advertisement of the event perpetuated the MFA's narrative on culture, particularly the culture of the Museum's own communities.

This chapter answers the questions, "how were people discussing the protests and the MFA over social media? And what were they saying?" I chose to do an analysis of the dialogic discourse created over Facebook using the key word search, Kimono Wednesdays. I did conduct research of content on Twitter, Youtube, and Tumblr, but found the amount of data relating to the protests on Facebook far surpassed these other outlets. Under time constraints, I chose to analyse most of the dialogic data from audiences on Facebook, while also including important information shared elsewhere on the internet.

I have elected to begin this analysis by first discussing my personal experience on Facebook discussions about the Kimono Wednesdays controversy. My early opinions and personal, albeit brief, engagement became the inspiration for this dissertation, and I felt it necessary to be clear that I had also participated in the online dialogue. Moving on, the remainder of this chapter discusses the analysis of the data collected from Facebook and then identifies how the online community interpreted the protesters' message. This research focuses on qualitative analysis and explores the variety of dialogic content that the Museum's audience expressed on Facebook. From this analysis, I conclude that there are two key issues in the Kimono Wednesdays protest: poor marketing delivery and a lack of risk-assessment management. 


\section{Facebook}

As I discussed in the research design section of the introduction, Google search results for "Kimono Wednesdays" provide a large number of news sources, blogs, vlogs, and tweets covering the controversy. Facebook, a social media website and mobile app, also appears in the Google search. However, as it is a semi-private application, searching from inside the Facebook application provided a larger number of dialogic results, including individual, organisational, page and group-related posts, from which data could be collected and analysed. Prior to analysis, I first organised the terminology and defined the parameters of data collection.

Below is the definition of terms used in the analysis of the Facebook comments:

- Newsfeed: this term refers to a series of posts and advertisements listed on the home page of an individual's account. Items posted into a newsfeed will appear in order of popularity or chronologically, based on the individual's preferential settings.

- $\quad$ Post: a post is content created by a person, organisation, or page and shared with their network of Facebook friends. ${ }^{1}$ As long as the poster does not take any action to privatise this content, this will display in a sequence of announcements within the newsfeed. Posts can display text, emoticons, images, videos, and Livestreams, or include linked articles from other media sources such as blogs, vlogs, and websites.

- Comments: these are responses to content in a post. There can be multiple comments within one post. Comments can be created by one or more people. More than one comment is often referred to as a thread. Content displayed in comments can be displayed similarly to posts (i.e. text, video, images, etc.).

- Replies: this refers to sub-comments that respond to a comment. There can be many replies within a comment. When this happens, it creates a thread within a comment and is usually a separate dialogue from the other comments in the post.

- $\quad$ Thread: there are two styles of a Facebook thread - a comment thread, where multiple comments respond to the post, and a thread within a comment, where several replies respond to one comment within a post. Comment threads can be

\footnotetext{
${ }^{1}$ A newsfeed is the centralised location for all posts. When an organisation or individual logs into Facebook, they are automatically taken to a newsfeed that highlights posts and comments made within their network. There is also a profile newsfeed. This shows all the posts made by the owner of the profile.
} 
organised by 'top comments' (showing only the most popular comments) or in chronological order.

Additionally, posts, comments, and replies show the date and time the content was created. If a comment was edited from its original content, the comment is shown with an updated creation date and listed as 'edited' on Facebook.

Below is a screen shot of a post I created to demonstrate the definitions above.

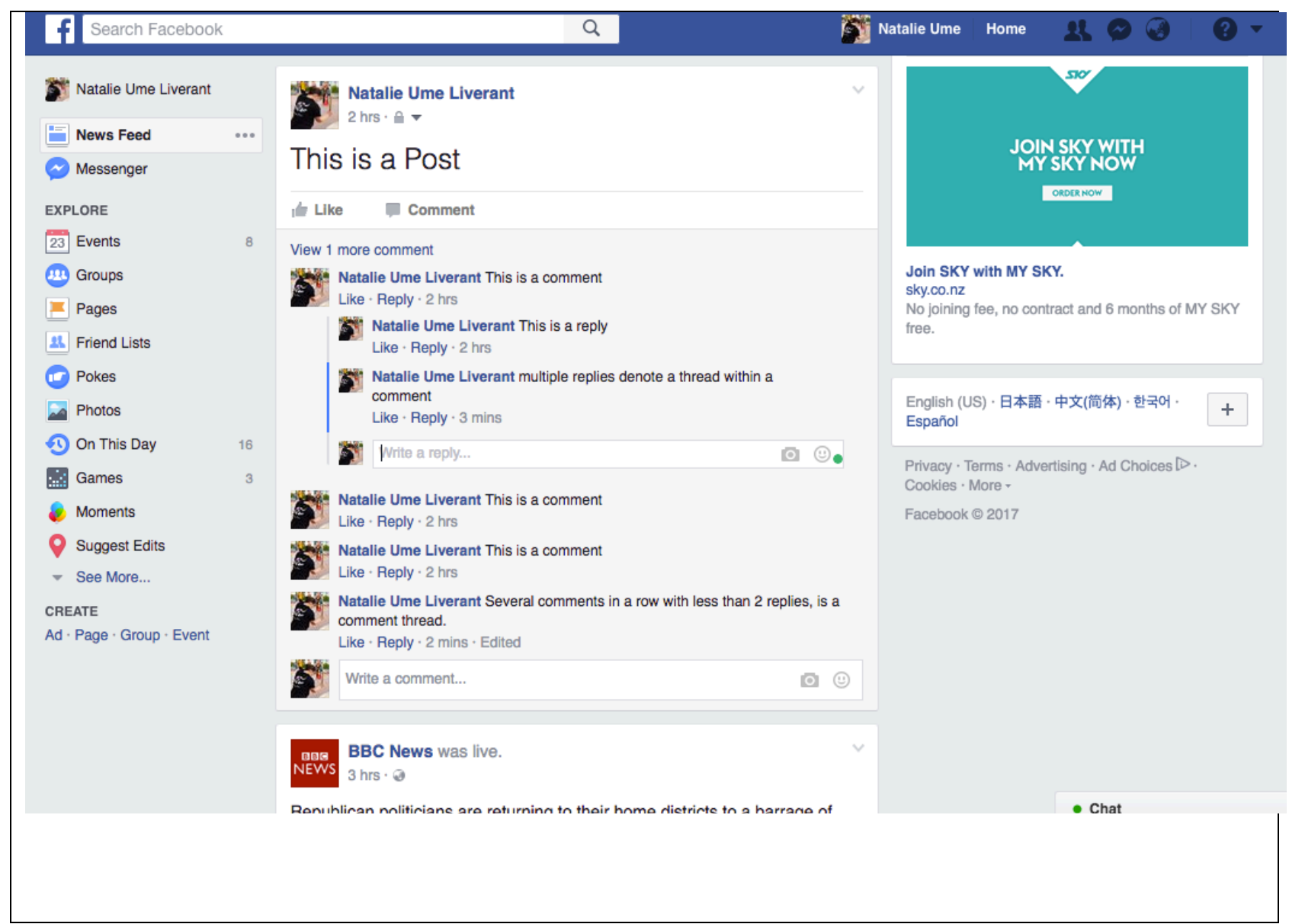

Figure 8: Demonstration of a post and a thread of comments and replies I made on my own Facebook newsfeed.

\section{My Kimono Wednesdays online participation}

I became aware of the Kimono Wednesdays programme after a member posted an article to a closed group on Facebook. The membership of this group has one criterion, to be or be associated with a ハーフ (hafu). The term, used in Japan, describes a person who is half 
Japanese by ancestry. ${ }^{2}$ The Hafu Japanese Facebook group serves as a virtual space where people can engage with others of a mixed Japanese background, interests, and life experience. The topics discussed here reflect the variety of the people that are a result of the Japanese diaspora. One of the popular narratives within this group focuses around the experience of being mislabelled as foreign, different, or exotic when residing in one's home country. Within the group, posts and comments often show solidarity, support, empathy, and encouragement to those who share their experience. The languages used within the group include English, Japanese, a blend of English and Japanese, or Romanised Japanese. There are also members of the group from other countries and it is not uncommon to have dialogic content created in multiple languages such as French, Spanish, Portuguese, and Icelandic.

On 7 July 2015, a post within the Hafu group brought my attention to the Kimono Wednesdays programme at the MFA. It stated:

Nao's your chance, go for it! ${ }^{3}$

Attached article "Outrage at the Boston Museum of Fine Arts". 4

As I discussed in Chapter 1, this article is one of the earliest reports I found on the Kimono Wednesdays event at the MFA. The writer briefs the reader on history of the painting, highlights the information from the museum about the painting's historical relevance to the Japonisme movement, and notes the intention for the visitor experience and some of the early comments by several objectors. My comment to this post reflected surprise and intrigue with the programme, but alluded very little to any other thoughts at the time:

Woah! What an [ellipsis used to show pause for emphasis] interesting [ellipsis] article and event. I'm currently working towards a Masters in Museum and Heritage, so my woah is multifaceted and too long winded to post. Thanks for sharing this article, [name omitted].

\footnotetext{
${ }^{2}$ For the description of the Hafu Facebook group guidelines, please check the Appendix. "Hafu Japanese", Facebook group, accessed December 17, 2016, https://www.facebook.com/groups/HafuJapanese/; Hafu definition: “About the Film," HAFU ハーフ: the film, accessed December 14, 2016, http://hafufilm.com/ en/about/; Nooshin Navidi, "Hafu Draws Viewers into World of Japanese Identity,” Japan Times, June 22, 2010, accessed December 14, 2016, http://www.japantimes.co.jp/community/2010/06/22/community/hafu-drawsviewers-into-world-of-japanese-identity/

${ }^{3}$ This is a bilingual pun or play on words. Nao is a common girl's name in Japan. To someone who speaks English, the pronunciation of "Nao" sounds similar to "now".

${ }^{4}$ Brian Boucher, "Outrage at Museum of Fine Arts Boston Over Disgraceful 'Dress Up in a Kimono' Event," Artnet News, July 6, 2015, accessed December 17, 2016, https://news.artnet.com/art-world/outrage-boston-museum-offine-arts-disgraceful-kimono-event-314534
} 
It was not until the next post,

"Follow-up; are there words for this?"

Attached article: Mainland art museum cancels 'Kimono Wednesdays' after uproar,"5

that I learned visitors were no longer permitted to try on the kimono but were still encouraged to engage by appreciating the feel of the fine texture and embroidery and attend the Spotlight discussions to address questions raised by the protests. In retrospect, my response to this post was poorly expressed. I had intended to engage in deeper discussion about the how the controversy could affect future programs at the MFA or elsewhere, because the staff feared a social backlash. I also wrongly presumed that I was engaging with the same audience who responded to the previous post and saw that I had identified myself as a museum studies student:

... this was a poorly executed program...this garment is not a kimono. I think it was lack of cultural insight that caused this program to fail so embarrassingly... I really believe this museum attempted something, new, dynamic [ellipses used to show pause] good(!), by trying to engage a broader audience. I am concerned that their education and public programming teams will see only where they failed and won't attempt... another program like this in the future... P.S. constructive critiques welcome, I need my brain and perspective expanded...

My comment was met with a single reply:

Curators at the MFA are no dummies, c'mon... mattaku! Masu masu tsukareru. [Interpretive translation: Good grief! I'm so annoyed/tired (though it isn't explicitly stated, the tone here and elsewhere in this comment feed alludes to the idea that the commenter is implying their disdain for what they believe is a stance that I am taking against the museum)]

I will admit that when reading this response, I was taken aback by the seemingly aggressive tone and criticism from the commenter. Trying to look past this comment as an affront to a carefully thought-out post, I contemplated whether I had not articulated my thoughts clearly enough to be understood by my audience. My intention had been to generate a conversation from the group on how a programme, like Kimono Wednesdays, could be better designed in the future, i.e. marketing, involving more communities in the planning process, etc. From my interpretation of the news, the protesters' upset was caused by the narrative of the marketing, but as I reflected on

\footnotetext{
${ }^{5}$ Associated Press, “Mainland Art Museum Cancels ‘Kimono Wednesdays’ After Uproar.”
} 
the reply to my comment, I wondered, did many people believe that the protests were about foreigners wearing kimono?

It was difficult for me to realise, but the 'Curators at the MFA are no dummies' reply eventually made me realise there was an error in my thinking. The reply insinuates museums and their staff are impervious to misinformation and misappropriation. This is a common stereotype that dates back to the days when museums were considered great pinnacles of knowledge. ${ }^{6}$ Understanding therefore that my commenter and I had different ideas about the protest movement and the operations within the Museum, my final response related to Kimono Wednesdays was in defence of my previous comment.

I didn't say curators. This is a program. It's developed by a Public Programming team...the people working on this program may not have experience in ethnic culture (art culture, yes! Usually [ellipsis]).

I also did not say anyone was a dummy nor did I insinuate anyone was, I clearly stated that the program lacked insight. What works in Japan for a predominantly Japanese audience and cultural perspective may or may not translate into something that would work for a different cultural audience...

While I didn't engage with comments or posts about Kimono Wednesdays thereafter, I was intrigued by the variety of comments and opinions being expressed online. It seemed that people had an opinion and they wanted to express it. This post ended after 68 comments, including two of mine. When I decided to analyse Facebook data, I used this post to develop the code for the 27 posts that I collected from Facebook.

\section{Data Collection of Kimono Wednesdays on Facebook}

From the search for "Kimono Wednesdays" in Facebook, the results appear in two categories:

1. Posts or comments made by someone in my network. This includes friends, groups, pages, and comments made by friends onto an account unaffiliated with me; however, this only happens when the other account is not strictly privatised.

2. Posts intended to be public; these can be made by an organisation, page, or individual with low privacy settings.

\footnotetext{
${ }^{6}$ Stephen E. Weil, Making Museums Matter (Washington, D.C.: Smithsonian Institution Press, 2002).
} 
In my data collection, there were only seven posts in category 1, that is, associated with my account. Broken down, there were four posts made by friends and three posts from the Japanese and Japanese-American Facebook Groups I am associated with. In contrast, the public search resulted in such a large selection of posts that I was unable to count them and, due to limits in time and resources, I chose the top 20 posts as they were listed in chronological order. Posts in this category were made by: high-profile individuals (5), news sources (6), open or public groups (8), and one individual whose profile was set to public.

In addition to these posts, I analysed comments and replies made to the posts. This involved some selection. A substantial number of comments and replies can occur in a single post. For example, one post had a comment thread 82 comments long. Of course, attempting to count, let alone analyse, the thread of replies within each of those comments would have required more time and resources than was available. Therefore, I took a sample of both comments and replies.

In chronological order, I selected the first 5 comments on each post and the first 5 replies to each comment. In total, 52 comments and replies were analysed. Posts were analysed separately from comments and replies. Below I describe in-depth the process applied for coding posts, comments, and replies.

\section{a. Coding}

The coding for the collected data helped to clarify the side and opinions the writer had of the Kimono Wednesday controversy. There were three main categories: neutral, pro-museum, and pro-protester. Overall, these categories are self-explanatory; neutral posts did not favour a particular side of the controversy, whereas pro-museum posts declared an alignment with the MFA and exhibit as it was originally created, and pro-protester posts faulted the museum and exhibit for wrong-doing against Japanese or Asian-Americans.

Next, I categorised each post based on the type of dialogic content expressed. I used the following codes to describe the tone, level of emotion, and presentation. In general, neutral posts asked questions and contained very little emotion. Posts of this nature were commonly identified as: 
Conversational: written to elicit a response, often directed at an individual or to the Facebook audience. Usually in the form of a question.

In the instance of a news site reporting on the Kimono Wednesdays protests, posts could also be:

Factual: presented in a style that provided information but did not engage with the viewership.

In contrast, pro-museum or pro-protester posts tended to be more emotional. Posts that took a side tended to be more critical. Levels of criticism ranged from:

- Sarcasm: slight or harshly judgemental statement directed at the opposite side in the form of a joke or condescending tone.

- Annoyance, irritation, upset: responding in a sneering or snickering fashion, but not reaching the same level of disrespect toward the opposite side as those writing in anger.

- Anger: reserved for content that was directly and intentionally offensive, using abusive or derogatory language toward the opposite side.

Posts were generally easy to analyse. The content was usually no more than one or two sentences. Whereas, comments and replies were more challenging as they tended to be longer and emotionally complex. This required re-analysis of the coding process.

Comments and replies were generally more dialogic. They tended to respond to a statement or question in a post and, in so doing, showed more emotive qualities, as well as conversational and/or factual content. Rather than creating another coding system. I extended the tone, emotion, and presentation section, allowing a comment to be coded with up to three additional codes. An example of this would be a comment that made an emotive response but also answered a question or provided information. Conversely, there were some shorter responses that were difficult to decipher and, without context or interviewing the individual behind the comment, too vague to code properly. For example, this response:

Stupid. Stupid. Stupid.

This was the first comment to the post: "Follow-up; are there words for this?" I discussed earlier. This comment was difficult to categorise. It clearly meant to take a side to the controversy, but without more context, it is unclear which side the comment favours; therefore, I created another 
code, 0 , to identify any data that was too difficult to analyse. Only three comments were given a 0 code.

It is important to note that search results were often written in English with the exception of a few posts and comments in French and Japanese. When possible, I included these comments and posts using my own elementary knowledge of the languages and the assistance of online dictionaries and translators.

\section{b. Findings}

i. Posts

Overall, the posts collected (28) showed an overwhelmingly neutral response (18 posts, or 64\%) and pro-museum and pro-protester split evenly ( 5 posts each, or 18\%). Every post included a link to an article from another website that discussed the Kimono Wednesdays protests. Neutral posts were usually inquisitive, trying to understand some or all of the thoughts and feelings behind the protests or from the Facebook audience. This is in contrast to pro-protester and pro-museum posts, which often took the form of statements and showed disdain for their opposition.

An example of a neutral post:

Are "Kimono Wednesdays" Insensitive or harmless fun?

An example of a pro-museum post:

We can't celebrate beautiful culture anymore... Everyone is offended. Idiocracy is real.

An example of a pro-protester post:

Kimono Wednesdays cancelled after people realize that you can't put on a culture like a funny hat.

There was one exception to the pro-museum post trend, where the poster was inquisitive instead of making a statement, as they tried to understand the mind-set of the Kimono Wednesdays protesters.

Legitimate question to anyone who holds this point of view: How is this racist or imperialist? 


\section{ii. Comments}

As I stated above, I only analysed a sample (52) of over 200 comments and replies from the posts collected for this data analysis. This sample reflects the first five chronological responses to a post or to a comment thread.

Similarly to posts, neutral comments and replies generally sought clarification about the protests or tried to provide information such as definitions or facts about the protesters, the programme or the MFA. The following four examples were taken from the comment section of the "Follow-up; are there words for this?” post I discussed previously, from the ハーフ Hafu group where I participated with comments of my own:

- Appropriate for the time and place?

- I don't understand [ellipsis]

- Was there some stipulation that only White people could do it?

- Here, I found it. It seems like very few or no Japanese people are involved tho(comment includes a defunct link to the Facebook group, created by protesters)

Unlike neutral comments, pro-museum or pro-protester comments showed a range of emotive and opinionated responses. Some attempted to support their claims with links or by providing definitions or reasoning for their emotive responses. Overwhelmingly, pro-museum comments and replies (41 comments or replies, or $78 \%$ ) far outweighed pro-protester (8 or 15\%). Below, I have provided examples to show the range of different emotive responses.

Sarcasm: poking fun/highlighting a perceived absurdity, occasionally insulting:

- "Ban the Mikado!"

- "Does this mean that I can't walk in the middle of my little street in Yukata, pull a cootie off the back of my neck dreaming of being Yojimbo any longer?"

Annoyed/irritated/wary/worrisome: less than angry but still offended/upset:

- "Should we not be more afraid of a blonde wearing a kimono acting inappropriately? We already have that stereotype."

- "Or family photos with the mom wearing a furisode. Yeah."

Angry: an intensely offended response, usually argumentative and occasionally insulting:

- "Words that wont [sic] pass muster in a family-friendly Facebook thread." 
- "I guess these people need to protest this little angel too for wearing a kimono and introducing Pocky to two people at a convention. Yeah, just try to protest my daughter [ellipsis]"

As I mentioned, some comments and replies required more than one code because of the variety in the content expressed. Below is an example of a comment that reflects on both perspectives of the protest before associating the post to the pro-museum side:

Such a fine line between cultural appreciation and appropriation. I think it's important to recognize that not all appreciation is appropriation and vice versa. Wearing an appropriate yukata or kimono correctly is not appropriation. However, white facing randomly in a kimono worn inappropriately is appropriation. I think using this exhibit to then highlight the beauty of a kimono is fine. Their delivery was just lacking and required more thought... At some point we should recognize that appreciating a culture also means ppl [sic] not of the culture will desire to participate. Appropriation vs appreciation - a very fine line.

\section{What was the Kimono Protest about?}

Overwhelmingly, the posts, comments, and replies discussed the Kimono Wednesdays protests as if the point was a discussion of whether or not non-Japanese people could wear kimono. Many comments used sarcasm to show disdain towards the protesters for protesting and later, for the MFA's decision to change the programme, limiting visitors to only "touch and engage with but not to try on" the garment. ${ }^{7}$ This dialogic discourse largely ignores the concerns brought up by the protesters of Kimono Wednesdays. As I discussed in Chapter 1, DOM argued that the event, as it was marketed:

...reaffirms the notion that Asian-identified folk are the Other, that they do not exist here, and that their cultures' histories with oppressive imperialist practices are mere entertainment fodder. Rather than interrogating these notions of cultural appropriation and Orientalism, the MFA has allowed its visitors to participate in a horrific display of minstrelsy. ${ }^{8}$

Instead, many of the conversational and factual comments discuss who, how, and when nonJapanese wearing kimono is considered appropriation or appreciation. Pro-museum comments largely reflected the following two responses:

\footnotetext{
7 "Press: July 2015," Museum of Fine Arts, Boston.

${ }^{8}$ Decolonize Our Museums, "Full Response to MFA 'Kimono Wednesdays."”
} 
- A friend in Japan states: "They love it here when foreigners wear kimono, I don't think anyone here would be offended by that, I think its [sic] a distinctly American way of thinking, being offended, and complaining that those protesting Asian Americans have."

- Its [sic] just a kimono! [Attached YouTube link] I'm sick of this "cultural appropriation" bullshit. Insulting a culture and wearing something from it are two different things.

Individuals who identified as from Japan or of Japanese heritage also engaged in the discussion. These posts and comments largely reflected the demeanour of the cultural authority:

- Haha. Probably I am racist and imperialist because I am from Japan.

- I'm proud to be Japanese, and I understand cultural appropriation is a thing, but this is political correctness gone to extremes. If people were showing up to this dressed as Daniel-san, I might be offended. But I think the museum didn't have any malicious intent.

The pro-protester comments also seemed to agree that the main issue was with museum visitors wearing kimono:

- My problem is that real traditional Japanese kimono is a ceremony process that is so complicated and precise it can take up to an hour to properly put on. The exhibit "costumized" the kimono, adding devaluation to the tradition and art of Japanese Kimono dressing. They took that red kimono and blonde haired painting and turned it into an express happy meal for the masses. That is NOT a real experience. I find it offensive, cheapened and accurately "American" in it's [sic] totality. Hashtag and everything provided... Sad.

One pro-protester's comment seemed to hint at the larger issues as outlined by DOM. However, it was difficult to understand what broader implications or issues Japanese-Americans (JAs) face and often ignore, as referred to by the commenter.

[name omitted], amazing to me the number of JAs who can't even consider that this might be inappropriate, and yet for really serious problems, they refuse to take a stand.

Interestingly, very few comments and replies (2 out of 52) discussed with each other their different perspectives on the topic of foreigners wearing cultural dress from an outside culture. Below is an example of this type of dialog:

- Interesting what you wrote, [directed to the previous commenter]. I recently travelled to India, where I considered buying traditional Indian clothing, but 
first asked a fellow Indian traveller from the US about a possible offense I might commit if I wore the clothing item (sari) to a public function back in the U.S., not being Indian. Was told I would not offend, but that I would be signalling my admiration/ appreciation for Indian culture/tradition.

- If you wear a sari you got on a trip to India to a party in the U.S., that's an act of appreciation. You've investigated the culture, and you're wearing it in a context where Indians would also wear it. If you start wearing your sari to work, that becomes more problematic. My mother wore saris every day of her adult life until her U.S. employers told her it was "unprofessional" to do so (physicians like my mother wear saris daily in India and it clearly has no bearing on their ability to practice). Protests around appropriation happen because communities of color are so frequently restricted from celebrating their own cultures freely in their daily lives that your freedom to celebrate a culture not your own is a painful reminder of a double standard.

\section{Summary}

I started this chapter with the question, "how were people talking about the MFA and Kimono Wednesdays protests and what were they saying?" Based on the results of this analysis, posts were generally informative. They didn't appear to take sides, only reporting in a few characters that a protest was happening in Gallery 255, with a link to a news article or other source. In contrast, comments and replies were more dialogic. They discussed or argued their feelings around the protests, in more emotive tones and lengthy discourse. However, it appears that there is some disconnect between the argument being made by DOM on their social media pages and the conversations around the protests happening on Facebook. Here, the focus of conversations was predominantly around the Kimono Wednesday controversy as a question of, "Can [sic] foreigners wear kimono?"9 I was unable to find direct sources as to why this particular narrative formed, but it is possible that initially, the Rage Against Yellow Face group on Facebook had made such a claim. The absurdity of the idea that foreigners should not wear kimono is expressed in many of the comments and replies, collected in the data.

Though, perhaps the best response to this argument is in the history of how the event was created in the first place. Given that the uchikake was created in Japan and that the garments were freely

\footnotetext{
${ }^{9}$ Rachel and Jun, Can Foreigners Wear Kimono? ボストン美術館・着物イベントに批判で中止? YouTube video, 8:38, posted by "Rachel and Jun," July 9, 2015, https://www.youtube.com/watch?v=kwoSYWIgV9Y
} 
given to the MFA, it seems to be a given that Japan had no issue with foreigners trying on the garment. ${ }^{10}$ What is unclear, perhaps, is when or how wearing a garment from a culture that is not your own could be considered inappropriate.

In Chapter 1, I pointed out that the blogger Keiko, from Japanese-American in Boston, noted that while overwhelmingly she opposed the idea that the MFA's event exhibited racist or orientalist intentions, she did agree that the title of the 15-minute companion discussions, Claude Monet: Flirting with the Exotic, was "cringe worthy". This point of view was echoed in an academic publication written by Julie Valk ${ }^{11}$ Here, perhaps, is where the heat of the controversy lies and also the fuel that provoked the protesters to gather in Gallery 255 and online. The design of this marketing drives a particularly European narrative and perspective of a culture, Japanese, as foreign and exotic. This was indeed accurate for a $19^{\text {th }}$ century audience, but $21^{\text {st }}$ century Americans are much more diverse. While this is merely speculative, perhaps it can be argued that the cringeworthy-ness mentioned by Valk and the Japanese-American blog has to do with this modern understanding of exoticism and sexualisation of Asian women. ${ }^{12}$

In Chapter 3, I will discuss the MFA's response to the Kimono Wednesday protests in the form of a public symposium, later uploaded to YouTube, and initiated by the new director, Matthew Teitelbaum.

\footnotetext{
${ }^{10}$ Julie Valk, "The 'Kimono Wednesday' Protests: Identity Politics and How the Kimono Became More Than Japanese," Asian Ethnology 74, no. 2 (2015): 395.

${ }^{11}$ Valk. "'Kimono Wednesday' Protests," 392; Japanese-American in Boston, "Monet's La Japonaise Kimono Wednesdays at the MFA."

12 Japanese-American in Boston, "Monet's La Japonaise Kimono Wednesdays at the MFA.”; Valk. "“Kimono Wednesday' Protests," 392.
} 


\section{Chapter 3}

The Museum Organises a Symposium

\section{Boston Museum of Fine Arts, Kimono Wednesdays: A Conversation}

Chapter 1 told the story of how the Kimono Wednesdays events were created at the MFA and the public backlash by a group of protesters, who eventually became DOM on Twitter, Tumblr and Facebook. Chapter 2 analysed a selection of posts, comments, and replies to the controversy discussed over Facebook. Here, I examined and identified the various approaches and tones used. The data shows that there was a strong misunderstanding that the Kimono Wednesdays protests were about prohibiting non-Japanese people from wearing a kimono. However, this misunderstanding belittles the larger issues raised by DOM on their Tumblr page.

This chapter answers the question, "how did the MFA respond to the Kimono Wednesdays protests. And, what did they say?" In the first section, I will review the posts made by the MFA over Facebook and Twitter, and on the Museum's website. Following this, I will discuss the twohour symposium organised by the Museum in February of 2016. I will discuss the responses made by the panellists, moderator, and new museum Director, Matthew Teitelbaum. This chapter will conclude by discussing how the MFA's facilitation of dialogue in this symposium was received and discussed on social media.

The MFA's online presence for Kimono Wednesdays

On 20 June 2015, at 3:52am, the MFA posted, on Facebook, a photograph of a young blonde woman in front of 'La Japonaise'. 'The woman was wearing one of the red replica uchikake donated to the Museum. With her hair twisted into a bun on the top of her slightly tilted head, her right arm extended out, gently flexed, waving an unfolded paper fan in the colours of the French flag, she was Monet's muse. A Camille Monet brought to life. The MFA elaborated on the photo:

Channel your inner Camille \#Monet and try on a replica of the kimono she's wearing in "La Japonaise." Every Wednesday night June 24-July 29, one of our College Ambassadors will be on hand to assist in transforming you into Monet's muse. Share your photos using \#mfaBoston!

\footnotetext{
${ }^{1}$ See figure 7 in chapter 1.
} 
Below is a selection of comments from the comment thread in this post. The early comments show an enthusiastic audience for the event:

3:53am "I like the interactive approach to art appreciation!"

5:05am "[name omitted] we need to do this. :-)"

5:08am “ボストン行きたい!”[I want to go to Boston!]

6:59am "[name omitted] let's go and do this OMG"

But, three days later, comments in this thread show the beginning of the Kimono Wednesdays protests:

23 June 2015, 2:00pm "NOT awesome. Simply racist. \#checkyourprivilage. Ugh."

23 June 2015, 7:44pm "I'm not Japanese, but at first glance, this offends me." 24 June 2015, 2:55am "Wow. Let's reduce cultural commentary to dress up, which is its own commentary."

Quickly thereafter, the comments and replies in this post evolved from the excited museum audience members to a debate comprised of pro-museum and pro-protest statements. Compared to the comments collected and analysed in chapter 2, which discussed the issue of foreigners wearing kimono, comments and replies in this post addressed other concerns around the protests. Below is a comment that discusses the issues of Asian stereotyping in the U.S. and raises the question of cultural authority.

11 July 2015, 8:45am "There are many different Asian cultures in the U.S. Growing up in the 70's, the people who made racist comments to me didn't distinguish between any of the subcultures: everyone was a chink. So in this sense, I can appreciate when people of Chinese or other Asian descent speak out about what they think is racist, even when the subject is Japanese culture. On the other hand, when most Japanese say they are not offended, but as a non-Japanese Asian, you insist that non-Asian people defer to your notion of racism, you perpetuate the stereotype that any particular Asian can represent / speak for all the others..."

The number of threads within comments grew as well. Some of the comments within this post received up to 42 replies. It is clear that many people felt the desire to express an opinion about the protest. Just as in those analysed in chapter 2 , the number of pro-museum comments far outweighed the number of pro-protest on this post made by the MFA. 
What I, and others writing about the protests, found the most interesting is how limited the MFA's response was while protests erupted in the galleries, on their post, elsewhere on Facebook, and over social media. ${ }^{2}$ During the protests and counter-protests, the MFA's social presence was silent. The only online acknowledgement of the Kimono Wednesdays protests made by the MFA was an apology on their website that notified the public that they would be changing the event.

...The kimonos will now be on display in the Impressionist gallery every Wednesday evening in July for visitors to touch and engage with, but not to try on. ... We will also increase the number of Spotlight Talks presented by MFA educators, to take place every Wednesday evening in July in conjunction with the display of the kimonos. The talks provide context on French Impressionism, "japonisme," and the historical background of the painting, as well as an opportunity to engage in culturally sensitive discourse. ... We apologize for offending any visitors, and welcome everyone to participate in these programs on Wednesday evenings, when Museum admission is free. We look forward to continuing the Museum's long-standing dialogue about the art, culture and influence of Japan. ${ }^{3}$

Although the MFA acknowledged the protest by issuing this apology, they continued to distance themselves from the conversation happening over social media.

The Museum of Fine Arts, Boston, awakes

I think most of the times museums are asleep. They're quiet, they're places that are empty, they really only come alive when audiences come and visit us, when visitors are in our spaces, when committed citizens bring ideas to the surface. It is people like you that make museums come alive. ${ }^{4}$

In January of 2016, six months after the Kimono Wednesdays controversy, the museum advertised, over Facebook, an event titled Kimono Wednesdays: A Conversation. ${ }^{5}$ The advertising described the event as a discussion between the audience and members of a panel. Panel members included a collection of scholars, a leading voice in DOM, and the Museum Director. Tickets to the event were free but were offered on a first-come, first-served basis.

\footnotetext{
2 Japanese-American in Boston, "Part 3: Kimono Wednesdays Protest Postmortem: MFA, My Role, Final Thoughts, Further Reading," blog post, August 31, 2015 (1:12AM), accessed February 27, 2017, http://japaneseamericanin boston.blogspot.co.nz/2015/08/part-3-kimono-wednesdays-protest.html

3 "Press: July 2015," Museum of Fine Arts, Boston.

${ }^{4}$ Matthew Teitelbaum in Museum of Fine Arts, Boston, Kimono Wednesdays: A Conversation.

${ }^{5}$ Museum of Fine Arts, Boston, Facebook newsfeed, accessed 7 July 2016, https://www.facebook.com/pg/ mfaboston/posts/
} 
According to the MFA's Facebook page, 160 people clicked 'attending' for the symposium. ${ }^{6}$ The symposium was held in an auditorium at the MFA on 7 February 2016. Afterwards, a video of the event was shared by the museum on their YouTube channel. ${ }^{7}$

For the conversation, the director of the MFA, Matthew Teitelbaum, gave the opening speech before seating himself among the panel. In addition, Jasmine Hagans, an MFA curator involved with the events, also made a speech. The remainder of the discussion (1.5 hours) was split between the panellists' prepared discussion topics and an audience question-and-answer session. Members on stage included the moderator, Elena Tajima Creef, professor of women's and gender studies at Wellesley College; and speakers Barbara Lewis, Director of the William Monroe Trotter Institute for the Study of Black History and Culture; Reiko Tomii, independent scholar and co-director of PoNJA-GenKon; ${ }^{8}$ Xtina Huilan Wang, DOM; and Ryan Wong, writer and visiting scholar at New York University’s Asian/ Pacific/American Institute.

It is interesting to note that Teitelbaum, as the MFA's new director, inherited the Kimono Wednesdays controversy and it appears that, when he became director, the MFA set out to work with DOM to create the symposium. In his speech, the tone was set for a lengthy discussion about museums, orientalism, implicit bias, the Asian-American experience, and history in the United States. He personified the museum (any museum) as a sleeping vessel, mustering awake with vibrancy only when visited by an engaged and activated community. He explained that museums have two roles: to care for the objects entrusted to them by the community and stakeholders, and to be a place that nurtures and encourages the ideas brought forth within the community, to be a place that is, in so many words, a "safe place for unsafe ideas". 9 Teitelbaum concluded his speech with an apology on behalf of the MFA for the unintentional hurt that the early advertisement of the Kimono Wednesdays events caused the Museum's Asian-American community.

\footnotetext{
${ }^{6}$ Clicking 'Attending' does not correlate to physical presence at the event as tickets must be purchased or ordered through an external sales website, and official attendance may be different on the day of the event.

${ }^{7}$ Museum of Fine Arts, Boston, Kimono Wednesdays: A Conversation.

${ }^{8}$ PoNJA-GenKon is an acronym (Post 1945 [Nineteen forty-five] Japanese Art Discussion Group / Gendai Bijutsu Kondankai) for a listserv on discussions on post-1945 Japanese art, established in 2003. "About PoNJAGenKon,” accessed February 17, 2017, http://www.ponja-genkon.net/AboutPoNJA.html

${ }^{9}$ Elaine Heumann Gurian, Civilizing the Museum: The Collected Writings of Elaine Heumann Gurian (London and New York: Routledge, 2006).
} 
Jasmine Hagans, a curator with the MFA, spoke next. She explained the history of how the Kimono Wednesdays events came to fruition and the intent of the tactile activity. She also explained how the MFA was 'caught off guard' by the passionate responses of socio-politically charged conversations in the museum and over social media to Kimono Wednesdays. Hagans acknowledged the large reaction over social media, indicating that it had affected the Museum profoundly. Since the protests, the MFA has sought to assess and change who the institution was engaging with, and how. ${ }^{10}$ She also explained that the MFA decided to make changes to the events after some protesters began to threaten to cause physical harm to other protesters and members of the museum.

The museum encourages online participation with \#whospeaks on Twitter

As she concluded her speech, Hagans asked the audience to use the hashtag \#whospeaks to help promote the discussion online. Later, the MFA would archive a collection of the tweets in chronological view. This continues to be accessible through the MFA's Twitter feed and provides an indication of specific comments or ideas which resonated with audience members.

\section{The panellists and conversation}

The conversation amongst the panel and audience addressed many of the feelings, questions and ideas of the Kimono Wednesdays controversy. Below are several of the key arguments made by the panellists presented during the symposium.

\section{What is Kimono?}

"Kimono is English, not a Japanese word.” Reiko Tomii ${ }^{11}$

A Japanese native, Professor Reiko Tomii explained how the word kimono, when used in English, describes a garment of Japanese influence or origin, and that this does not equate to the same meaning of 着物 (kimono) in Japanese. She discussed how the use and definition of "kimono" in English exemplifies an oversimplification, common with other borrowed words, to

\footnotetext{
${ }^{10}$ Museum of Fine Arts, Boston, Kimono Wednesdays: A Conversation.

${ }^{11}$ Reiko Tomii in Museum of Fine Arts, Boston, Kimono Wednesdays: A Conversation.
} 
describe traditional and cultural garments from outside the Western cultural context. This broad definition fails to reveal the intricate details around the history, various uses, styles, structured classism, economic status, and symbolism of traditional clothing. She explained that this is not limited to kimono but can be seen in other 'English' words, such as sarong, sari, and kilt. In her comments, she examined the definition of the Western use of the word "kimono". Using an online English dictionary, she showed the audience that a kimono is defined as a floor length robe, with long sleeves and a sash. She also pointed out that a kimono is a garment often interpreted to be worn predominantly by women. Contradicting this, in Japan, "kimono" means "thing to wear": an umbrella term for garments worn by men, women, and children, and further identified by season, occasion, marital status, and class. In the modern Japan, kimono are often worn for special occasions, including graduations, weddings, and funerals.

How does the Western overgeneralisation of kimono change how the garments are worn, designed, and appreciated? Tomii explained how the contemporary world of fashion designers who use the basic structure and rules of kimono, reinvent its use for a modern society. Highlighting kimono aficionados, sometimes in reference to otaku culture, she showed the audience how this group of people dedicate themselves to learning about the various forms and styles of kimono to create wearable art that embraces tradition but also provides new ways to embrace this cultural icon, thus making it a global garment.

Why is there a difference between a museum holding a 'try-on' kimono event in Japan and one in the U.S.?

Xtina Huilan Wang, who represented DOM, stressed that the protests were not trying to restrict who put on the uchikake. Rather, they were meant to provoke discussion and understanding around a deeper issue of context and representation in the U.S. She denounced the criticism that the protesters, who were largely non-Japanese Asian, were trying to speak for Japanese and Japanese-American people. Instead, they were criticising those who were relating the narrative of Japanese culture and how they were doing this.

This is not about banning kimonos. I am not interested in that. I am pro kimono. But I am not pro the kimono being used as a kind of fetish item or a way of garnishing and glorifying Western beauty. Which is what the painting does. It centers a white woman who uses accoutrements of the east to extenuate her 
whiteness and her beauty. So, the kimono is being used in a way in which it's stripped of its cultural context. That's what I am protesting against. ${ }^{12}$

Wang expressed that when the event was created in Japan, for a Japanese audience for whom kimono is woven into the social tapestry of everyday life, there was no harm in wearing a garment from one's own country and appreciating it in the shoes of an outsider. As Tomii discussed, there are many types and styles of kimono. This particular uchikake was not an everyday garment. Art historians and kimono aficionados have explained that the uchikake, with the particularly fine, but boldly styled, embroidery and the specific placement of the samurai at the bottom half, was a costume used for Kabuki theatre. ${ }^{13}$ The event, it could be argued, was akin to similar situations in the West, where people dress up in elaborate costumes from different time periods, such as Victorian dress, and take photos.

However, Wang's point is that the Kimono Wednesdays events and discussions are not congruous with the same events in Japan. She and other members of the panel and audience emphasised that the U.S. has a complex history of immigration, racism, and marginalisation of minorities, including Asians. Furthermore, the objective of the protests, and later the intention by the MFA when Hagans promoted \#whospeaks, alludes to the importance of asking museums and their audiences to look critically at how culture is appropriated within the context of museum environments. During the question-and-answer section of the symposium, many in the audience argued that traditionally, museums, as well as educational institutions, tell the story of America from a white or colonist perspective.

To emphasis Wang's point, the panellist moderator, Professor Elena Tajima Creef directed the audience's attention toward word choice in the promotion of the event:

What plays well in Japan does not necessarily translate neatly or parallel to what we do in the West. [It is a] very different context. There is not a history of racist Yellowface performance in Japan. We [in America] are already embedded in the West and maybe [pause] 2000 years of thinking about the othering of non-western people in a white Euro-American tradition. ... [In] the original advertising, you

\footnotetext{
${ }^{12}$ Xtina Huilan Wang in Museum of Fine Arts, Boston, Kimono Wednesdays: A Conversation.

${ }^{13}$ Gedo, Monet and His Muse, 172-174; Koikishu "Stylish Master", "Outrage at Museum of Fine Arts Boston over Disgraceful 'Dress Up in a Kimono’ Event,” Tumblr post, July 7, 2015, accessed February 17, 2017, http://koikishu.tumblr.com/post/123481976622/tokyo-fashion-outrage-at-museum-of-fine-arts
} 
can see how problematic the language was, Flirting with the Exotic and the whole notion, the white privileging of unleashing your inner Camille. Where does this place Asian [or Asian-American] people who, like Reiko, wanted to dress up in the uchikake? I guess [as an Asian woman trying to] unleash your inner white woman, playing in an Asian/Japanese stereotype or fantasy. ${ }^{14}$

\section{Where did the Museum go wrong?}

Throughout the panel discussion, Ryan Wong, along with other points, said that he was less interested in discussing what happened during Kimono Wednesdays and more interested in discussions around how museums need to consider narrative story telling after this controversy. Toward the end of the panel discussion, he reflected on the social media advertisement:

Having worked for a museum, I know for a fact that a lot of people looked at this and were like... Ya, that looks good to me. A lot of people had to sign off on this. When we talk about racism today, a lot of people still think racism means calling someone a dirty name. That is actually not the most important type of racism that faces us. The most important racism that faces us are institutional and structural. Institutional in this case, means a lot of people looking at this and not finding anything wrong with it OR if they did find something wrong with it maybe not having the space to express that. Maybe because they were not in a position of power. What I want to point out is that this is an opportunity to really think about who gets to speak within institutions. What if the MFA made it part of their mission statement to be a leader in saying this is an opportunity to really examine how museums can branch out into the world and address these diverse topics. That is what I hope comes out of this. ${ }^{15}$

Wong's statement mirrors other museum literature on relevancy, inclusivity, and restructuring. ${ }^{16}$ Later, in response to a question by a member of the audience, MFA Director Matthew Teitelbaum made a similar statement. He acknowledged that the MFA needed to reflect on the history of their objects and the demographics of their communities, and ask deeper questions of who is telling the story when creating an event or programme.

I believe we exist in a time when there is less certainty about what the definition of an identity might be. ...Moments like [Kimono Wednesdays] gives [the Museum] the opportunity, better than we might, to understand how complex these issues are and what constitutes an appropriate engagement with history and which history. ${ }^{17}$

\footnotetext{
${ }^{14}$ Elena Tajima Creef in Museum of Fine Arts, Boston, Kimono Wednesdays: A Conversation.

${ }^{15}$ Ryan Wong in Museum of Fine Arts, Boston, Kimono Wednesdays: A Conversation.

${ }^{16}$ See Lonetree, Decolonizing Museums; Lynch, Whose Cake...?; Simon, Participatory Museum.

17 Matthew Teitelbaum in Museum of Fine Arts, Boston, Kimono Wednesdays: A Conversation.
} 


\section{Summary}

This chapter sought to understand the behaviour of the MFA before, during, and after the Kimono Wednesdays controversy. As was already discussed in the Gronemann et al. study, museums tend to shy away from dialogic co-constructive discourse on Facebook. They warn that there are potential tensions in continuing this behaviour and that it is imperative for museums to create processes to provide for dialogic discourse on museum objects and events. ${ }^{18}$ What can be seen in the Kimono Wednesdays controversy is the manifestation of the tensions discussed in the Gronemann et al. study.

The words chosen for the marketing of the events Claude Monet: Flirting with the Exotic and Kimono Wednesdays show how a museum can enthusiastically promote an event without reflective considerations for the community who may be interested to attend and participate. While it is likely that the museum was unaware that the titles and execution of the events would be upsetting to a particular demographic, the lack of response to the protests, both online and within Gallery 255, seem to have perpetuated further tensions. As Hagans mentioned in her speech, the decision to alter the event was made in response to threats of violence. However, this move seemed to embolden the frustrations online and the counter-protesters organising in Gallery 255 during the last two weeks of the event.

Kimono Wednesdays: A Conversation was an unconventional move by the MFA to embrace the controversy and make an effort to address the issues raised by the protesters and counterprotesters. There were many statements and ideas discussed over the two hours. At times, the audience grew heated, making some of the audio difficult to hear. At the end of the video, it was clear that there were many issues that the audience wanted to discuss and that the conversation around cultural narrative and perspective is far from concluded. However, to answer the questions outlined in the beginning of this chapter, the MFA's response during the symposium was also minimal. This approach may have been chosen by the new director, who wanted these specific communities to have the chance be their own voice in the institution, or as he mentioned in his opening speech, to make the MFA come alive.

\footnotetext{
${ }^{18}$ Gronemann, Kristiansen and Drotner, "Mediated Co-construction."
} 
In the hands of the new director, Matthew Teitelbaum, the MFA engaged in conversations with DOM and organised an open and public symposium. Throughout the symposium, the public was provided a platform and the freedom to discuss the issues and concerns raised in the Kimono Wednesdays controversy. It is likely that the MFA chose this option in order to build a stronger rapport with their local and online-based audiences. Unfortunately, to know if this symposium achieved this, further research needs to be conducted.

The following chapter is the Conclusion, where I discuss the lessons museums can take away from Kimono Wednesdays and the kind of further research needed for museums with a social media presence. 


\section{Conclusion}

\section{Even Monkeys Fall from Trees, 猿も木から落ちる \\ a Japanese Proverb}

This research provides an in-depth case study of a museum interaction with audiences on social media in the "Age of Protest". It addresses a gap in the literature around audiences using social media to fuel museum-centred debate and discussion. In order to answer the question "How are museum audiences using social media platforms in the Age of Protest?", I chose to analyse a sample of dialogic discourse from Facebook users who engaged in online discussions about the Kimono Wednesdays protests at the MFA. I analysed the Museum's response to the protest and organisation of a public symposium, Kimono Wednesdays: A Conversation. The culmination of museum audience and MFA interactions on the Internet have lead me to further considerations in regard to research and processes of museums using social media with respect to current social temperament.

When Gronemann et al. did a study on the level of co-constructive dialogue museums employ in their posts and comments over Facebook, the results showed that, by and large, museums continued to perpetuate behaviours of the institution as the holders of knowledge and authority. The use of authoritative voice in the context of non-dominant cultures has been heavily discussed in recent museum literature. Black, Lonetree, Lynch, Russo, Simon, and others have written on the need for museums to apply various models of co-construction, partnership, and reflexive practice to produce a many-to-many level of engagement between museums and audiences. In her critical review of her own work on collaboration and partnerships between museums and communities, Lynch explains how museums can achieve relevancy through reflective practice.

Reflective practice is intended to be an ongoing process, embedded within the organisation's normal ways of working - a back and forth process of communication to which the organisation must commit so as to avoid continuing the situation of organisational dominance. ${ }^{1}$

\footnotetext{
${ }^{1}$ Lynch, Our Museum.
} 
Perhaps, because museum engagement over Web 2.0 applications is relatively new and tends, as discussed in Gronemann et al, to focus largely on what museums can do online, there exists very little literature on the adaptations of reflective practice and collaboration with social media based audiences. It is evident from research on Internet usage that social media, as a tool to communicate and share ideas, will continue to grow demographically in terms of age and its global span. The current Internet climate is one of information sharing and mobilising, and this has led to an increased level of moral outrage manifesting itself in an Age of Protest. Given this current environment, institutions wanting a positive public image and engagement with diverse audiences will need to embrace long-term reflective practices with online audiences. Kimono Wednesdays has provided valuable insight into the diverse opinions and responses that exist among museum audiences. Below, I have reflected on the elements of Kimono Wednesdays analysed in this research to provide four suggestions on processes for museums' social media presence moving forward.

\section{Tweet carefully}

There used to be a childhood chant to counter verbal bullying: "Sticks and stones may break my bones but your words can never hurt me”. The truth is, words can hurt. Words combined with particular behaviours can elicit strong emotions. When the MFA promoted their events Kimono Wednesdays on Facebook and Instagram, they meant to portray a playful and unique tactile experience for their visitors. Unfortunately, the vernacular they chose was ill suited for a $21^{\text {st }}$ century audience. Flirting with the Exotic was meant to represent a $19^{\text {th }}$ century European perspective of Oriental otherness. America today, however, is culturally more diverse. In the time since Camille posed for La Japonaise, a diaspora of people from Asian countries, including Japan, has infiltrated many Western countries. In the U.S. particularly, there is a complex history, approaching 170 years, of objectification, racial exclusion, racial incarceration, and targeted racial violence. ${ }^{2}$ Despite this, there continues to be a growing population of Asians and Asian-Americans in the U.S.. ${ }^{3}$

\footnotetext{
${ }^{2}$ For an overview of the history and experience of Asians in America please see: Roger Daniels, Asian America: Chinese and Japanese in the United States since 1850 (Seattle: University of Washington Press, 1988).

3 "Minority Health: Asian American Populations," Centers for Disease Control and Prevention, accessed February 27, 2017, https://web.archive.org/web/20130615015135/http://www.cdc.gov:80/minorityhealth/populations /REMP/asian.html
} 
As mentioned in the Introduction there is an increased moral awareness of issues through the use of social media. As more people become aware of history and current behaviour that has a moral dimension, praise or outrage can ensue. Kimono Wednesdays brought together a group of strangers, predominantly Asian-Americans, who felt uncomfortable about the vernacular used in the marketing of the event. They attempted to engage the museum to discuss issues with the title and activity of the event and, fuelled by a lack of response from the MFA, this group organised and quickly mobilised into a protest. Through the use of social media, this protest was propelled into the international spotlight, turning a small voice of concerned minority citizens into a largescale controversy. With the rising use of social media as a platform to mobilise, it is essential that museums be conscious of the words and characters used in advertising and engagement over social media. But, just as words can hurt, words can also heal. This leads to the next suggestion.

\section{Engage with audiences when they voice concerns}

The DOM Tumblr cited "Lack of Response" as one of their issues with the MFA and why they were protesting the Kimono Wednesdays events. Keiko, the writer for the Japanese-American in Boston blog, also wrote that the museum's silence during the protests was disappointing. It is difficult to speculate on how the protests would have changed if the MFA had chosen to communicate with the protesters at an earlier stage of the protests, rather than organising a symposium six months later. However, it is clear from the discussions held during the symposium that a line of communication directly with the museum was an important element in moving on from the protest. Institutions need to treat direct audience-to-museum engagement as a crucial point of dialogue and co-construction. As such, it would be ideal if museums chose to respond in a timely manner to concerns expressed over email and through social media. A way to get ahead of the curve on this may be to use reflective processes at several levels of a project that allow for a diversity of thoughts and ideas from within the community.

\section{Acknowledge different interpretations and perceptions of content}

Kimono Wednesdays: A Conversation demonstrated how one word, borrowed from a foreign language, can have new meaning, similar but still different, from the original native definition. 
This concept can be applied to the many objects and interpretations on display in a museum today. Given the diverse communities of many Western museums, it is crucial to consider the narrative presented. As Lonetree and Catlin-Legutko explain about decolonising museums, traditional vernacular used in the display and interpretation of objects of Native Americans reflects a dominant European perspective. This is no longer acceptable practice, particularly where the cultural demographics of the populations are diverse. To combat this, institutions must establish and maintain meaningful relationships with communities.

\section{Develop on-going practices with the community, both physically and online}

Here I draw heavily from Lynch and Simon's work on participation and partnership building of museums and their communities. It is crucial in this era of social media that museums choose to develop impactful relationships with the communities around them. Both Lynch and Simon discuss the challenging nature of meaningful relationships between museums and communities. In Lynch's study, many of the museums her team worked with reverted to their traditional modes of operations, leaving their communities feeling marginalized in exhibitions and in respect to the content related to them. ${ }^{4}$ Simon discusses how change has to come from within, with every member of the museum actively engaging with the community. ${ }^{5}$ Together, they prove by example in their own institutions how meaningful relationships can be developed and maintained.

Tweet Carefully, Museums is an in-depth analysis of how museum audiences used social media to discuss and engage in protest around the MFA's events Claude Monet: Flirting with the Exotic and Kimono Wednesdays. A limitation of this research is that it focuses on a single case study from an online perspective. This is not indicative of all museum audience engagement online. Further research could be undertaken to examine other ways in which audiences are using social media to engage with museum-centred discussions and debate; how marketing and engagement by museums on social media affects audience engagement, visitation, and experiences; and how to produce social media-specific strategies for communication and museum-audience relationships. To my knowledge, Kimono Wednesdays is a unique example

\footnotetext{
${ }^{4}$ Lynch, Whose Cake...?, 21-22.

${ }^{5}$ Simon, Participatory Museum, 7.
} 
that was driven by American specific issues of racial stereotypes and history. Atypical or not, the relevance of conducting further research is not diminished and the museum sector could certainly benefit from more case studies.

It would also be beneficial to conduct more research on new methods of co-constructive discourse and engagement specifically for social media. There is little doubt that social media has become a tool across the global landscape. The next step for museums is to learn how to use this tool in many-to-many models of communication and engagement, which will allow institutions to remain relevant in accordance with the three elements discussed by Black: demographic change, generational shifts, and the rise of new media. ${ }^{6}$ The sector could certainly benefit from more in-depth qualitative and quantitative data in this area.

The current age of social media offers museum audiences a new way to engage with museums. This research showed how this change in landscape is raising questions regarding \#whospeaks in an institution, for culture, and, for people. As the social media landscape continues to form, there will have to be in place evolving processes and strategies to develop meaningful dialogic coconstruction. It will not be an easy or smooth journey, but as a Japanese proverb reminds us: Even Monkeys Fall from Trees. 猿も木から落ちる。

\footnotetext{
${ }^{6}$ Black, "Developing Audiences," 125.
} 


\section{Glossary}

Black Ships - 黒船 kurofune is the Japanese reference to the arrivals of Western ships to Japan: the first in the 16th century and the last in the 19th century. DOM - Decolonize Our Museums, a Tumblr account developed from the Rage Against Yellowface page that was created on Facebook in protest of the Kimono Wednesdays event at the MFA.

Furisode - 振袖 A furisode is an elaborate kimono, with long sleeves that often just touch the ground, worn by unmarried women for special occasions. After a woman is wed, the sleeves of her kimono must be shortened to the appropriate length to symbolise the nuptial agreement.

$\mathrm{Hafu}$ - ハーフ is a term used in Japanese to describe people who are half or mixed Japanese heritage residing in Japan. This term has been borrowed by other mixed Japanese around the world.

Hōmongi - 訪問着 refers to a type of kimono that is worn to dress up when going out with friends or for a modest special occasion. This garment can be worn by married or unmarried women, but the styles vary according to marital status. A hōmongi is traditionally gifted to a woman when she marries as a symbol of the nuptial agreement she has engaged in.

Japonisme - a French term also used in English to refer to the fashionable trend and influence of Japanese aesthetics on Western culture. This began after Japan, an isolated country for over 200 years, was invaded by Matthew Perry in 1854, and forced into signing a trade agreement with the Americans.

Kimono - 着物 in Japanese this translates literally as 'wearable thing'. In English, it is commonly used to refer to a robe-like garment, tied with a wide belt or sash, worn by women.

NHK - 日本放送協会 Nippon Hōsō Kyōkai, the national broadcasting corporation of Japan. It is popularly referred to by its acronym.

Otaku - オタク In Japan, this traditionally referred to a 'computer geek', typically a male who was obsessed with gaming and computers and frequented the 秋葉原(Akihabara) district in 東京(Tokyo). Today, there are several categories: in Japan, it commonly refers to a male who is obsessed with the fantasy world of popular music girl groups, anime (tv and video animation), and manga (comic novels). Outside of Japan, it refers to foreigners of any gender who are obsessed with several or particular Japanese genres, including: J-pop (Japanese popular music), anime, manga, cosplay (dressing as characters from anime and manga), and gaming.

Pocky® - A type of Japanese sweet. It is a thin, stick-like wine biscuit coated in chocolate or various flavours, strawberry and green tea, to name a few. 
PoNJA-GenKon- is an acronym (Post Nineteen forty-five Japanese Art Discussion Group / Gendai Bijutsu Kondankai) for a listserv on discussions on post-1945 Japanese art, established in 2003.

Romanji (or romanisation) - is the use of English letters to spell a word from Japanese (i.e. good morning おはようございます as ohayo gozaimasu).

Sensu - 扇子 a popular style of folding fan, which, when opened, can be used to create a breeze. Popular in many cultures.

Tweet - similar to, but often shorter than a Facebook post, a tweet can only be up to 140 characters in length. It can contain pictures, short video, or a link to a source outside of the Twitter application.

Uchikake - 打掛 a type of 着物 (kimono), traditionally worn by women of high social class at the time of their wedding or, more commonly, worn in theatrical reproductions such as Noh or kabuki theatre. In these instances, the uchikake was likely to be worn by an 女方 (onnagata) or male actor playing a female role.

Uchiwa - 団扇 a Japanese style fan that is round with a long stick handle. This cannot be folded closed.

Yojimbo - 用心棒 the title of an Akira Kurasawa film from the 1960s about a 浪 人(rōnin), a lordless samurai who arrives in a small town in the midst of a power battle between two crime lords. Both try to hire the rōnin for protection.

Yukata - 浴衣 a light, thin, kimono worn by men and women in summer. 


\section{Figures}

Figure 1. Claude Monet, La Japonaise,1867. Available from the Museum of Fine Arts, Boston, accessed 27 February 2017. http://www.mfa.org/collections/conservation/conservation-inaction/la-japonaise

Figure 2. Conservation in Action, from the Museum of Fine Arts, Boston, accessed 27 February 2017. http://www.mfa.org/collections/conservation/conservation-in-action/la-japonaise

Figure 3. @worldofkiirotori, 'To celebrate the holding of "Japonisme Exhibition Splendid Museum of Fine Arts, Boston” exhibition at Setagaya Art Museum in Japan, Rilakkuma items were created with the representative work of this exhibition - The "La Japonaise" by Claude Monet'. Digital image, from Instagram, accessed December 16, 2016. https://www.instagram.com/p/rLtoAfuvHU/

Figure 4. @zitting_cisticola, 'Special Exhibition’. Digital image, from Instagram, accessed December 16, 2016. https://www.instagram.com/p/qy-wm3gh-8/

Figure 5.@dkdksao, ‘美しさの極外’. Digital image, from Instagram, accessed December 18, 2016. https://instagram.com/p/lwTPRCw5sA/

Figure 6. @moereil45, digital image, from Instagram, accessed 15 February 2017. https://www.instagram.com/p/rJMERglryb/

Figure 7. Facebook post of "Channel Your Inner Camille Monet...”, posted by the Museum of Fine Arts, Boston, on 20 June 2015, accessed 18 July 2016.

https://www.facebook.com/mfaboston/photos/a.157948467320.125412.28314922320/1015291 $2478132321 /$

Figure 8. Demonstration of a post, comment, reply, and thread. Created on my (Natalie Ume Liverant) personal Facebook profile, 23 February 2017. 


\section{Appendix: Guidelines for the Hafu Japanese Facebook group}

Sourced from https://www.facebook.com/groups/HafuJapanese/, accessed 17 December 2016

\section{DESCRIPTION}

\section{TO JOIN THE GROUP:}

1) Please read the below text and make sure you are eligible to join.

2) If you are, click “Join Group”.

3) Monitor your inbox, including your "other" folder (accessible from the web only, under Messages -> Other (next to Inbox)). The admins will contact you within a few days.

\section{PLEASE READ THIS BEFORE REQUESTING TO JOIN:}

Hafu Japanese is a community where hafus from all over the world can meet, discuss, and share experiences regarding their hafuness. (Food is also ALWAYS a welcome topic.)

This group is a discussion forum for hafus and parents/children/spouses of a hafu. To clarify, hafu is the Japanese term for people who are half Japanese. The minimum age to join is 18 .

**Please do not request to join if you are not half Japanese or a family member of a half Japanese person or if you are under $18 .^{* *}$

This group is not intended for those who do not meet the above description or are merely interested in cultural exchange, Japanophiles, anime otakus, date seekers etc. There are lots of groups on Facebook for other hapas and those who just live in Japan or are interested in Japan.

\section{COMMUNITY GUIDELINES:}

- Be respectful. If you have negative comments about someone, keep them to yourself. Please remember that we have a number of cultural and linguistic backgrounds here and many of us write in a second or third language.

- Be careful with anything regarding religion, politics or historical events.

- Personal attacks, harassment and threats are not allowed.

- Respect privacy. Do not post personal disputes or private messages for the whole group to read.

- Hate speech and racism will not be tolerated in any form. Do not use racial slurs such as the n-word or the j-word.

- Refrain from advertising your business or fan/community page or posting spam. If what you do is hafu- or Japanrelated, it is probably of interest to the group and sharing is welcome, but please refrain from soliciting. When in doubt, you can always contact the admins and ask.

The Hafu photography project:

http://www.hafujapanese.org/

The Hafu documentary:

http://www.hafufilm.com/

The Hafu documentary on Facebook:

http://on.fb.me/b2glIJ 


\section{Bibliography}

Badovinac, Zdenka, and Bartomeu Marí. Museums Beyond the Crises: CiMAM 2012 Annual Conference Publication. UK, Cambridge Scholars Publishing, 2015.

Baxter, Pamela, and Susan Jack. "Qualitative Case Study Methodology: Study Design and Implementation for Novice Researchers." The Qualitative Report, Vol 13 Number 4 (December 2008): 544-559.

Black, Graham. "Developing Audiences for the Twenty-First Century Museum” in The International Handbooks of Museum Studies: Museum Practice, 1st edition, edited by Conal McCarthy, 123-151. Chichester, West Sussex: John Wiley \& Sons, Ltd., 2015.

Brown-Haysom, Ryan. "Religious Objects in Museums: Private Lives and Public Duties. (Book review)." Review of book by Crispin Paine. Museum Worlds 2 (2014): 235-240.

Conn, Steven. Do Museums Still Need Objects? Philadelphia: University of Pennsylvania Press, 2010.

Crooke, Elizabeth. “The 'Active Museum': How Concern with Community Transformed the Museum," in The International Handbooks of Museum Studies: Museum Practice, 1st edition, edited by Conal McCarthy, 481-500. Chichester, West Sussex: John Wiley \& Sons, Ltd., 2015.

Daniels, Roger. Asian America: Chinese and Japanese in the United States since 1850. Seattle: University of Washington Press, 1988.

Denscombe, Martyn. The Good Research Guide: For Small-Scale Social Research Projects. New York: McGraw-Hill Education, 2013.

Diamond, Judy, Jessica J. Luke, and David H. Uttal. Practical Evaluation Guide: Tool for Museums and Other Informal Educational Settings. $2^{\text {nd }}$ ed. Nashville, Tennessee: AltaMira Press, 2009.

Effing, R., J. van Hillegersberg, and T. Huibers. "Social Media and Political Participation: Are Facebook, Twitter and YouTube Democratizing Our Political Systems?" In Electronic Participation, ePart 2011. Lecture Notes in Computer Science, vol 6847, edited by E. Tambouris, A. Macintosh, and H. de Bruijn. Berlin: Springer-Verlag Berlin Heidelberg, 2011.

Ellison, Nicole B., Jessica Vitak, Charles Steinfield, Rebecca Gray, and Cliff Lampe. "Negotiating Privacy Concerns and Social Capital Needs in a Social Media Environment." In Privacy Online: Perspectives on Privacy and Self-Disclosure in the Social Web, edited by Sabine Trepte and Leonard Reinecke, 19-32. Berlin: Springer-Verlag Berlin Heidelberg, 2011.

Fahy, Anne. "New Technologies for Museum Communication," in Museum, Media, Message, edited by Eilean Hooper-Greenhill, 82-96. London: Routledge, 1995.

Fell, Georgina, "Going Social: A Case Study of the Use of Social Media Technologies by the Museum of New Zealand Te Papa Tongarewa," MMHS diss., Victoria University of Wellington, 2012. 
Fois, Valentina. "The Prosumer: The Key Player of the Museum of the Future." Proceedings of the Conference on Electronic Visualisation and the Arts (EVA '15). Swindon UK: BCS Learning \& Development Ltd., 2015: 291-297. Accessed January 28, 2017. DOI: https://doi.org/10.14236/ewic/eva2015.32.

Gedo, Mary Mathews. Monet and His Muse: Camille Monet in the Artist's Life. Chicago: University of Chicago Press, 2010.

Giaccardi, Elisa, ed. Heritage and Social Media: Understanding Heritage in a Participatory Culture. New York: Routledge, 2012.

Grincheva, Natalia. "Cultural Diplomacy 2.0: Challenges and Opportunities in Museum International Practices" Museum \& Society, 11(1), (March 2013), 39-49. ISSN 1479-836.

Grofman, Bernard, Alexander H. Trechsel, and Mark Franklin, eds. The Internet and Democracy in Global Perspective: Voters, Candidates, Parties, and Social Movements. Switzerland: Springer International Publishing, 2014.

Gronemann, Sigurd Trolle, Erik Kristiansen and Kirsten Drotner. "Mediated Coconstruction of Museums and Audiences on Facebook," in Museum Management and Curatorship 30 (2015): 174-190. Accessed September 7, 2015. doi: 10.1080/09647775.2015.1042510

Gurian, Elaine Heumann. Civilizing the Museum: The Collected Writings of Elaine Heumann Gurian. London and New York: Routledge, 2006.

Harrison, Julia D. "Ideas of Museums in the 1990s." In Heritage, Museums, and Galleries: An Introductory Reader, edited by Gerard Corsane, 38-53. London and New York: Routledge, 2005.

Hein, George E. “'The Museum as a Social Instrument': A Democratic Conception of Museum Education." In Museum Gallery Interpretation and Material Culture, edited by Juliette Fritsch, 13-25. New York: Routledge, 2011.

Henning, Michelle. Museums, Media, and Cultural Theory: Issues in Cultural and Media Studies. London: McGraw-Hill Education and Open University Press, 2006. Hooper-Greenhill, Eilean. Museums and their Visitors. London: Routledge, 1994. Hooper-Greenhill, Eilean. Museums, Media, Message. London: Routledge, 1995. Howard, Philip N., and Muzammil M. Hussain. Democracy's Fourth Wave?: Digital Media and the Arab Spring. New York: Oxford University Press, 2013.

Karp, Ivan, Christine Mullen Kreamer, and Steven D. Lavine, eds. Museums and Communities: The Politics of Public Culture. Washington, D.C.: Smithsonian Institution Press, 1992.

Knell, Simon J., Suzanne Macleod, and Sheila E. R. Watson, eds. Museum Revolutions: How Museums Change and are Changed. London and New York: Routledge, 2007.

Lonetree, Amy. Decolonizing Museums: Representing Native America in National and Tribal Museums. Chapel Hill, NC: University of North Carolina Press, 2012.

Lynch, Bernadette. Whose Cake is it Anyway?: A Collaborative Investigation into Engagement and Participation in 12 Museums and Galleries in the 
UK (Summary Report) London: Paul Hamlin Foundation, 2011.

Lynch, Bernadette. Our Museum: A Five-Year Perspective from a Critical Friend.

London: Paul Hamlyn Foundation, 2016.

Obar, Jonathan A. and Steven S. Wildman. "Social Media Definition and the Governance Challenge: An Introduction to the Special Issue." Telecommunications Policy, 39(9) (2015): 745-750. Quello Center Working Paper No. 2647377.

Parry, Ross. Recoding the Museum: Digital Heritage and the Technologies of Change. London and New York: Routledge, 2007.

Russo, Angelina. "Transformations in Cultural Communication: Social Media, Cultural Exchange, and Creative Connections." Curator: The Museum Journal 54 (2011): 327-346. Accessed May 8, 2016. doi:10.1111/j.2151-6952.2011.00095.x.

Russo, Angelina, Jerry Watkins, Lynda Kelly, and Sebastian Chan. "How Will Social Media Affect Museum Communication?” In Proceedings Nordic Digital Excellence in Museums (NODEM), Oslo: Norway, 2006.

Simon, Nina. The Participatory Museum. Santa Cruz, CA: Museum 2.0, 2010.

Simon, Roger. "Remembering Together: Social Media and the formation of the Historical Present." In Heritage and Social Media: Understanding Heritage in a Participatory Culture, edited by Elisa Giaccardi, 89-106. New York: Routledge 2012.

Valk, Julie. “The 'Kimono Wednesday' Protests: Identity Politics and How the Kimono Became More Than Japanese.” Asian Ethnology 74, no. 2 (2015): 379-399.

Watson, Sheila, ed. Museums and their Communities. London: Routledge, 2007.

Weil, Stephen E. Making Museums Matter. Washington, D.C.: Smithsonian Institution Press, 2002.

Westerman, David, Patric R. Spence, and Brandon Van Der Heide. (2014), "Social Media as Information Source: Recency of Updates and Credibility of Information.” Journal of Computer-Mediated Communication, 19 (2) (Jan 2014): 171-183. doi:10.1111/jcc4.12041.

Yin, Robert K. Case Study Research: Design and Methods, 3rd edition. Thousand Oaks, CA: Sage Publications, Inc., 2003.

Yin, Robert K. Case Study Research: Design and Methods, 5th edition. Thousand Oaks, CA: Sage Publications, Inc., 2014. 


\section{Online Bibliography}

Asia for Educators, Columbia University. "Commodore Perry and Japan (1853-1854)."

Accessed February 27, 2017. http://afe.easia.columbia.edu/special/japan_1750_perry.htm Associated Press. "Mainland Art Museum Cancels 'Kimono Wednesdays' After Uproar."

Honolulu Star Advertiser. July 7, 2015. Accessed March 29, 2016. http://www.staradverti ser.com/2015/07/07/breaking-news/mainland-art-museum-cancels-kimono-wednesdays-a fter-uproar/

Black Lives Matter. "Home.” Accessed February 14, 2017. http://blacklivesmatter.com/

Boucher, Brian. "Outrage at Museum of Fine Arts Boston Over Disgraceful 'Dress Up in a Kimono' Event.” Artnet News, July 6, 2015. Accessed December 17, 2016. https://news.artnet.com/art-world/outrage-boston-museum-of-fine-arts-disgracefulkimono-event-314534

Briceno, Eduardo. The Power of Belief_Mindset and Success | Eduardo Briceno | TEDxManhattanBeach. YouTube video, 10:51. Posted by “Tedx Talks," November 18, 2012. Accessed May 26, 2016. https://www.youtube.com/watch?v=pN34FNbOKXc

Bring Back Our Girls. "Home." Accessed February 14, 2017. http://www.bringbackourgirls.ng/

Bruni, Frank. "How Facebook Warps Our Worlds." The New York Times, May 21, 2016. Accessed May 22, 2016. http://www.nytimes.com/2016/05/22/opinion/sunday/howfacebook-warps-our-worlds.html

Catlin-Legutko, Cinnamon. We Must Decolonize Our Museums | Cinnamon Catlin-Legutko | TEDxDirigo. YouTube video, 9:23. Posted by “Tedx Talks,” December 6, 2016. Accessed February 26, 2017. https://www.youtube.com/watch?v=jyZAgG8--Xg\&t=316s

Centers for Disease Control and Prevention. "Minority Health: Asian American Populations". Accessed February 27, 2017.

https://web.archive.org/web/20130615015135/http://www.cdc.gov:80/minorityhealth/pop ulations/REMP/asian.html

Decolonize Our Museums. "Full Response to MFA 'Kimono Wednesdays' + 'Flirting with the Exotic'.” Tumblr post. July 29, 2015. Accessed 30 January 2017. http://decolonizeourmuseums.tumblr.com/post/125348836324/full-response-to-mfakimono-wednesdays

Decolonize Our Museums. Tumblr page. Accessed January 30, 2017. http://decolonizeourmuseums.tumblr.com

Decolonize Our Museums. Twitter Page. Accessed October 20, 2016. https://twitter.com/decolonizeom

Edmunds, Susan, and Julie Iles. "Businesses Need Good Social Media Policies to Manage Risk." Stuff News, February 20, 2017. Accessed February 20, 2017. http://www.stuff.co.nz/business/89551636/businesses-need-good-social-media-policiesto-manage-risk

Einspruch, Franklin. "Boston Kimono Alarms Culture Crusaders." The Federalist, July 10, 2015. Accessed January 7, 2017. http://thefederalist.com/2015/07/10/boston-kimono-alarmsculture-crusaders/

Fell, Georgina. "Going Social: A Case Study of the Use of Social Media Technologies by the Museum of New Zealand Te Papa Tongarewa." reCollections, Volume 9, Issue 1, (April 2014) ISSN 1833-4946. Accessed May 6, 2016.

http://recollections.nma.gov.au/issues/volume_9_number_1/papers/going_social 
Francis, Vic. "Virgin in a Condom Provokes Outcry." Christianity Today, June 15, 1998. Accessed February 20, 2017. http://www.christianitytoday.com/ct/1998/june15/8t719b.html

Friedman, Thomas L. "The Age of Protest." The New York Times, January 13, 2016. Accessed February 2, 2017. https://www.nytimes.com/2016/01/13/opinion/the-age-of-protest.html

Frist Center for the Visual Arts. "Looking East: Western Artists and the Allure of Japan." Accessed January 28, 2017. http://fristcenter.org/calendar/detail/looking-east-western-artand-the-allure-of-japan

Google. "How Search Works.” Accessed February 27, 2017. http://www.google.co.nz/insidesearch/howsearchworks/thestory/

Google. "Self-Driving Car [Waymo, as of December 2016]." Accessed 29 November 2016. https://www.google.com/selfdrivingcar

Gottfried, Jeffrey, and Elisa Shearer. "News Use Across Social Media Platforms 2016." Pew Research Center: Journalism \& Media. May 26, 2016. Accessed February 18, 2016. http://www.journalism.org/2016/05/26/news-use-across-social-media-platforms-2016/

HAFU ハーフ: the film. “About the Film.” Accessed December 14, 2016. http://hafufilm.com/en/about/

Hammond, Jeff Michael. "How Japan's Art Inspired the West." The Japan Times, August 14, 2014. Accessed January 24, 2017. http://www.japantimes.co.jp/culture/2014/08/14/arts/how-japans-art-inspired-the-west/

Hosch, William L. "Machine Learning." Encyclopaedia Britannica Online Academic Edition. Accessed January 7, 2017. https://www.britannica.com/technology/machine-learning Internet World Statistics. "Internet World Users by Language." Accessed October 17, 2016. http://www.internetworldstats.com/stats7.htm

Japanese-American in Boston. "Monet's La Japonaise Kimono Wednesdays at the MFA." Blog post, July 7, 2015 (4:20PM), modified July 13, 2015. Accessed January 27, 2017. http://japaneseamericaninboston.blogspot.co.nz/2015/07/monets-la-japonaise-kimonowednesdays.html

Japanese-American in Boston. "Part 1: Kimono Wednesdays Protest Postmortem: Media, Public, Critics.” Blog post, August 31, 2015 (1:12AM). Accessed January 27, 2017. http://japaneseamericaninboston.blogspot.co.nz/2015/08/part-1-kimono-wednesdaysprotest.html

Japanese-American in Boston. "Part 2: Protest and Counterprotest @ July 15th Kimono Wednesday.” Blog post, July 17, 2015 (2:38AM). Accessed February 27, 2017. http://japaneseamericaninboston.blogspot.co.nz/2015/07/part-2-protest-andcounterprotest-july.html

Japanese-American in Boston. "Part 3: Kimono Wednesdays Protest Postmortem: MFA, My Role, Final Thoughts, Further Reading.” Blog post, August 31, 2015 (1:12AM). Accessed February 27, 2017. http://japaneseamericaninboston.blogspot.co.nz/2015/08/part-3-kimono-wednesdaysprotest.html

神徳, 昭甫.“日本開国－異文化交錯の劇空間.”人文学部紀要40 (2004): 85-167.

Khawaja, Mansoor, Bill Boddington, and Robert Didham. Growing Ethnic Diversity in New Zealand and its Implications for Measuring Differentials in Fertility and Mortality. Wellington: Statistics New Zealand, 2007. Accessed February 17, 2017. http://www.stats.govt.nz/ /media/Statistics/browse-categories/population/census- 
counts/review-measurement-ethnicity/growing-ethnic-diversity.pdf

Khosla, Vinod. "Do We Need Doctors or Algorithms?" TechCrunch.com, January 10, 2012. Accessed January 27, 2017. https://techcrunch.com/2012/01/10/doctors-or-algorithms/

Koikishu "Stylish Master". "Outrage at Museum of Fine Arts Boston over Disgraceful 'Dress Up in a Kimono' Event." Tumblr post. July 7, 2015. Accessed February 17, 2017. http://koikishu.tumblr.com/post/123481976622/tokyo-fashion-outrage-at-museum-offine-arts

Kyoto and Nara Dream Trips! "La Japonaise by Monet in Kyoto!” Blog post, November 2, 2014 (9:28PM). Accessed January 23, 2017. www.kyotodreamtrips.com/la-japonaise-monetkyoto/

McFeeters, Stephanie. "Counter-Protesters Join Kimono Fray at MFA.” Boston Globe, July 19, 2015. Accessed January 27, 2017.

https://www.bostonglobe.com/arts/2015/07/18/counter-protesters-join-kimono-fray$\mathrm{mfa} / \mathrm{ZgVWiT3yIZSIQgxCghAOFM/story.html}$

Mitchell, Amy, Jeffrey Gottfried, Michael Barthel, and Elisa Shearer. "The Modern News Consumer: 1. Pathways to News." Pew Research Center: Journalism \& Media. July 7 , 2016. Accessed February 18, 2017. http://www.journalism.org/2016/07/07/pathways-tonews/

Musée National Des Beaux-Arts du Québec. "Looking East: Western Artists and the Allure of Japan.” Accessed January 28, 2017. https://www.mnbaq.org/en/exhibition/looking-east1227

Museum of Fine Arts, Boston. “About the MFA.” Accessed January 22, 2017. www.mfa.org/about

Museum of Fine Arts, Boston. "Conservation in Action: La Japonaise, March 2013." Accessed January 27, 2017. http://www.mfa.org/collections/conservation/conservation-in-action/lajaponaise/march-2013

Museum of Fine Arts, Boston. Facebook newsfeed. Accessed July 7, 2016. https://www.facebook.com/pg/mfaboston/posts/

Museum of Fine Arts, Boston. Kimono Wednesdays: A Conversation. YouTube video, 2:03:30. P osted by Museum of Fine Arts, Boston. February 12, 2016. Accessed January 9, 2017. htt ps://www.youtube.com/watch? $v=$ M0m8qaXrus\&t $=3475 \mathrm{~s}$

Museum of Fine Arts, Boston. "La Japonaise (Camille Monet in Japanese Costume)." Accessed January 23, 2017. www.mfa.org/collections/object/la-japonaise-camillemonet-in-japanese-costume-33556

Museum of Fine Arts, Boston. "Nagoya/Boston Museum of Fine Arts." Accessed January 23, 2017. http://www.mfa.org/exhibitions/mfa-on-tour/nagoya

Museum of Fine Arts, Boston. "Nagoya/Boston Museum of Fine Arts: History of Exhibitions." Accessed January 23, 2017. www.mfa.org/news/nagoya-exhibition-history

Museum of Fine Arts, Boston. "Press: July 2015.” Accessed July 2, 2016. http://www.mfa.org/news/2015/july

Museum of Fine Arts, Boston. "Publication." Accessed August 8, 2016. http://www.mfa.org/collections/publications/looking-east-0

Museum of Fine Arts, Boston. "Special Event: Cheers to Malcolm!” Accessed January 28, 2017. http://www.mfa.org/programs/special-event/cheers-to-malcolm

Museum of Fine Arts, Boston. “The Museum Year 2009: Director's Message.” Accessed January 22, 2017. www.mfa.org/annual-report-2009/director.html 
Museum of New Zealand Te Papa Tongarewa. "Home.” Accessed February 20, 2017. https://www.tepapa.govt.nz/

Nagoya/Boston Museum of Fine Arts. "About Us.” Accessed January 22, 2017. www.nagoyaboston.or.jp/english/about/outline.html

Nagoya/Boston Museum of Fine Arts. "Looking East: Western Artists and the Allure of Japan, From the Museum of Fine Arts, Boston. Accessed January 27, 2017. http://www.nagoyaboston.or.jp/english/exhibition/past/japonisme-201501.html

Navidi, Nooshin. "Hafu Draws Viewers into World of Japanese Identity.” Japan Times, June 22, 2010. Accessed December 14, 2016.

http://www.japantimes.co.jp/community/2010/06/22/community/hafu-draws-viewersinto-world-of-japanese-identity/

No DAPL. "Home." Accessed February 14, 2017. http://www.nodapl.life/

O’Dwyer, Shaun. "Of Kimono and Cultural Appropriation." The Japan Times, August 4, 2015. Accessed October 22, 2016. http://www.japantimes.co.jp/opinion/2015/08/04/commentary/japancommentary/kimono-cultural-appropriation/

O’Neil, Andrea. "'Virgin in a Condom' artwork provoked violence month after Te Papa Opening." The Dominion Post, March 21, 2015. Accessed May 30, 2016. http://www.stuff.co.nz/dominion-post/capital-life/67466278/virgin-in-a-condom-artworkprovoked-violence-month-after-te-papa-opening

O’Reilly, Tim. "What is Web 2.0.” Accessed May 29, 2016. ehttp://www.oreilly.com/pub/a/web2/archive/what-is-web-20.html

Occupy Wall Street. "Latest News.” Accessed February 14, 2017. http://occupywallst.org/

Perception Institute. "Implicit Bias." Accessed December 6, 2016. www.perception.org/research/implicit-bias/

Pet Cube. "Home." Accessed February 20, 2017. https://petcube.com/

Pew Research Center: Internet \& Technology. "Social Media Fact Sheet." Updated January 12, 2017. Accessed February 18, 2017. http://www.pewinternet.org/fact-sheet/social-media/

Pew Research Center: Internet \& Technology. "Social Media Update 2016." Updated November 11, 2016. Accessed February 20, 2017. http://www.pewinternet.org/2016/11/11/socialmedia-update-2016/

Pew Research Center: Internet \& Technology. "Social Media Usage: 2005-2015.” Updated October 8, 2015. Accessed January 27, 2017. http://www.pewinternet.org/2015/10/08/social-networking-usage-2005-2015/

PoNJA-GenKon. “About PoNJA-GenKon.” Accessed February 17, 2017. http://www.ponja-gen kon.net/AboutPoNJA.html

Poushter, Jacob. "Smartphone Ownership and Internet Usage Continues to Climb in Emerging Economies." Pew Research Center: Global Attitudes \& Trends, February 22, 2016. Accessed February 18, 2017. http://www.pewglobal.org/2016/02/22/smartphoneownership-and-internet-usage-continues-to-climb-in-emerging-economies/

Rachel and Jun. Can Foreigners Wear Kimono? ボストン美術館・着物イベントに批判で中 止? YouTube video, 8:38. Posted by "Rachel and Jun," July 9, 2015. Accessed June 2, 2016, https://www.youtube.com/watch?v=kwoSYWIgV9Y

Rodney, Seph. "The Confused Thinking Behind the Kimono Protests at the Boston Museum of Fine Arts." Hyperallergic, July 17, 2015. Accessed July 7, 2016. https://hyperallergic.com/223047/the-confused-thinking-behind-the-kimono-protests-at- 
the-boston-museum-of-fine-arts/

Rosen, Larry, and Keith N. Hampton. "Is Technology Making People Less Sociable?" The Wall Street Journal, May 10, 2015. Accessed June 1, 2016. http://www.wsj.com/articles/istechnology-making-people-less-sociable-1431093491

せたがや Setagaya City. “あなたも「ラ・ジャポネーズ」になれる！世田谷美術館でワー クショップ開催 [You can be 'La Japonais'! Workshop held at the Setagaya Art Museum].” Accessed January 29, 2017. http://www.city.setagaya.lg.jp/kurashi/107/159/778/h26/d00134505.html

Stanford University. "Machine Learning." Coursera online course. Accessed November 29, 2016. https://www.coursera.org/learn/machine-learning

Statista: The Statistics Portal. "Number of Mobile Phone Users Worldwide from 2013 to 2019 (in billions)." Accessed October 17, 2016. https://www.statista.com/statistics/274774/forecast-of-mobile-phone-users-worldwide/

Support for Kimono Wednesday's [sic] at BMFA. Facebook group. Accessed October 22, 2016. https://www.facebook.com/groups/1141781712515378

The Physics arXiv Blog. "When a Machine Learning Algorithm Studied Fine Art Paintings, It Saw Things Art Historians Had Never Noticed." Medium.com. Accessed February 27, 2017. https://medium.com/the-physics-arxiv-blog/when-a-machine-learning-algorithmstudied-fine-art-paintings-it-saw-things-art-historians-had-neverb8e4e7bf7d3e\#.rt4qo9mgm

Wenner, Jan S. "The Day After: Obama on His Legacy, Trump's Win and the Path Forward." Rolling Stone, November 29, 2016. Accessed December 15, 2016. http://www.rollingstone.com/politics/features/obama-on-his-legacy-trumps-win-and-thepath-forward-w452527

Wikipedia contributors. "List of Largest Art Museums." Wikipedia, The Free Encyclopedia. Accessed January 22, 2017. https://en.wikipedia.org/wiki/List_of_largest_art_museums Wikipedia contributors. "Takarazuka Revue.” Wikipedia, The Free Encyclopedia. Accessed January 28, 2017. https://en.wikipedia.org/wiki/Takarazuka_Revue

Wikipedia contributors. "Web 2.0." Wikipedia, The Free Encyclopedia. Accessed June 1, 2016. https://en.wikipedia.org/wiki/Web_2.0

Yuco. “ボストン美術館の「ラ・ジャポネーズ論争」[Boston Museum’s 'La Japonaise Controversy'].” Blog post, July 10, 2015 (22:03PM). Accessed January 23, 2017. https://note.mu/yuco/n/n30a6f37c7fb0 